\title{
Three-dimensional evolution of Saharan dust transport towards Europe based on a 9-year EARLINET-optimized CALIPSO dataset
}

\author{
Eleni Marinou $^{1,2}$, Vassilis Amiridis ${ }^{1}$, Ioannis Binietoglou ${ }^{1,3}$, Athanasios Tsikerdekis ${ }^{5}$, Stavros Solomos $^{1}$, \\ Emannouil Proestakis ${ }^{1,4}$, Dimitra Konsta ${ }^{1}$, Nikolaos Papagiannopoulos ${ }^{6}$, Alexandra Tsekeri ${ }^{1}$, Georgia Vlastou $^{8}$, \\ Prodromos Zanis ${ }^{5}$, Dimitrios Balis ${ }^{2}$, Ulla Wandinger ${ }^{7}$, and Albert Ansmann ${ }^{7}$ \\ ${ }^{1}$ IAASARS, National Observatory of Athens, 15236 Athens, Greece \\ ${ }^{2}$ Department of Physics, Aristotle University of Thessaloniki, 54124 Thessaloniki, Greece \\ ${ }^{3}$ National Institute of R\&D for Optoelectronics, Magurele, Romania \\ ${ }^{4}$ Laboratory of Atmospheric Physics, Department of Physics, University of Patras, 26500 Patras, Greece \\ ${ }^{5}$ School of Geology, Aristotle University of Thessaloniki, 54124 Thessaloniki, Greece \\ ${ }^{6}$ Consiglio Nazionale delle Ricerche, Istituto di Metodologie per l'Analisi Ambientale (CNR-IMAA), Tito Scalo (PZ), Italy \\ ${ }^{7}$ Leibniz Institute for Tropospheric Research, 04318 Leipzig, Germany \\ ${ }^{8}$ Department of Physics, National and Kapodistrian University of Athens, Athens, Greece
}

Correspondence to: Eleni Marinou (elmarinou@noa.gr)

Received: 7 October 2016 - Discussion started: 24 November 2016

Revised: 6 March 2017 - Accepted: 21 March 2017 - Published: 12 May 2017

\begin{abstract}
In this study we use a new dust product developed using CALIPSO (Cloud-Aerosol Lidar and Infrared Pathfinder Satellite Observation) observations and EARLINET (European Aerosol Research Lidar Network) measurements and methods to provide a 3-D multiyear analysis on the evolution of Saharan dust over North Africa and Europe. The product uses a CALIPSO L2 backscatter product corrected with a depolarization-based method to separate pure dust in external aerosol mixtures and a Saharan dust lidar ratio (LR) based on long-term EARLINET measurements to calculate the dust extinction profiles. The methodology is applied on a 9-year CALIPSO dataset (2007-2015) and the results are analyzed here to reveal for the first time the 3-D dust evolution and the seasonal patterns of dust over its transportation paths from the Sahara towards the Mediterranean and Continental Europe. During spring, the spatial distribution of dust shows a uniform pattern over the Sahara desert. The dust transport over the Mediterranean Sea results in mean dust optical depth (DOD) values up to 0.1. During summer, the dust activity is mostly shifted to the western part of the desert where mean DOD near the source is up to 0.6. Elevated dust plumes with mean extinction values between 10 and $75 \mathrm{Mm}^{-1}$ are observed throughout the year at various heights between 2 and $6 \mathrm{~km}$, extending up to latitudes of
\end{abstract}

$40^{\circ} \mathrm{N}$. Dust advection is identified even at latitudes of about $60^{\circ} \mathrm{N}$, but this is due to rare events of episodic nature. Dust plumes of high DOD are also observed above the Balkans during the winter period and above northwest Europe during autumn at heights between 2 and $4 \mathrm{~km}$, reaching mean extinction values up to $50 \mathrm{Mm}^{-1}$. The dataset is considered unique with respect to its potential applications, including the evaluation of dust transport models and the estimation of cloud condensation nuclei (CCN) and ice nuclei (IN) concentration profiles. Finally, the product can be used to study dust dynamics during transportation, since it is capable of revealing even fine dynamical features such as the particle uplifting and deposition on European mountainous ridges such as the Alps and Carpathian Mountains.

\section{Introduction}

Mineral dust is ubiquitous in the atmosphere and one of the main contributors to the global aerosol load (Zender et al., 2004; Textor et al., 2006), with almost half of the global dust emissions generated in Africa (Huneuus et al., 2011). This has large consequences for air quality downwind (Viana et al., 2002; Gobbi et al., 2007), for the radiative budget due 
to scattering, absorption, and emission of solar and terrestrial radiation (Balkanski et al., 2007), as well as for cloud formation and lifetime (e.g., DeMott et al., 2003; Levin et al., 2005; Koren et al., 2010). These effects depend strongly on the vertical distribution of dust. For example, dust particles will have a stronger impact on shortwave radiation absorption when they are located above bright clouds (Yorks et al., 2009; Winker et al., 2013). Moreover, dust atmospheric lifetime is much longer in the free troposphere than in the planetary boundary layer, and, upon entering the free troposphere, dust particles can be transported across vast areas, altering the geographic pattern of their impacts (Prospero and Lamb, 2003; Levin et al., 2007; Ridley et al., 2012). Finally, the dust vertical distribution is crucial for dust-cloud interactions (e.g., Mamouri and Ansmann, 2016; Nickovic et al., 2016). Therefore, observing, monitoring and quantifying the atmospheric dust burden and especially its vertical distribution is an important step towards understanding the climatic role of dust (IPCC, 2013, WG1, chap. 5, 7 and 9).

Lidar is the most prominent tool for aerosol profiling and has largely contributed to our knowledge of the vertical distribution of the dust optical properties (e.g., Liu et al., 2002; Ansmann et al., 2003; Balis et al., 2004; Papayannis et al., 2008; Mona et al., 2012; Granados-Muñoz et al., 2016; Bovchaliuk et al., 2016). Polarization lidar observations greatly expand the capabilities for dust detection, as non-spherical dust particles have a distinct signature on the particle depolarization ratio (e.g., Z. Liu et al., 2008; Tesche et al., 2009). In Europe, the European Aerosol Research Lidar Network (EARLINET; Pappalardo et al., 2014) operates advanced lidar systems employing depolarization techniques that have been invaluable for dust research. Moreover, sophisticated methodologies developed in EARLINET allow the complete characterization of different aerosol types including dust (e.g., Papayannis et al., 2008) as well as the dust contribution to the total aerosol load (Tesche et al., 2009).

The Cloud-Aerosol Lidar and Infrared Pathfinder Satellite Observation (CALIPSO) mission equipped with the CloudAerosol Lidar with Orthogonal Polarization (CALIOP) instrument has been delivering aerosol and cloud profiles across the globe for more than 10 years (Winker et al., 2009). This dataset offers the possibility to characterize the three-dimensional spatial distribution of aerosol as well as its temporal variation. CALIPSO is established as an accurate and robust means for mineral dust identification from space (Liu et al., 2008; Omar et al., 2009). The application of EARLINET methodologies on CALIPSO observations can improve the observations for mineral dust research, as already suggested and applied in Amiridis et al. (2013). Specifically, this study retrieves the extinction of pure dust from CALIPSO with high accuracy, applying the depolarization-based separation method introduced by Tesche et al. (2009), coupled with a regionally uniform climatological LR (lidar ratio) for calculating dust extinction. The latter is estimated from long-term EARLINET measure- ments (Wandinger et al., 2010; Baars et al., 2016). It has been shown that the EARLINET-optimized CALIPSO dust product presented in Amiridis et al. (2013) is in better agreement with Aerosol Robotic Network (AERONET) collocated measurements over the Sahara and Europe and with Moderate Resolution Imaging Spectroradiometer (MODIS) measurements over the Mediterranean for collocated cells with low cloudiness. This product is considered as the first accurate dust retrieval from space, since dust discrimination methods applied on passive sensors are based on the separation of the fine from coarse particle mode (e.g., Kaufman et al., 2005), delivering mostly biased DODs (dust optical depths) over the oceans due to the contamination of the coarse mode by sea salt particles (Su et al., 2013). Another advantage of the EARLINET-optimized CALIPSO dust product is its capability to provide accurate dust retrievals over all surface types, since CALIOP uses its own light source, overcoming the surface reflectance limitations of passive sensors (e.g., Hsu et al., 2004; Sayer et al., 2012).

Many studies have used satellite observations to derive dust properties over the Mediterranean during the last 15 years. Most of them focus on the horizontal distribution of dust using passive remote sensing techniques. Antoine and Nobileau (2006) used SeaWIFS (Sea-viewing Wide Field-of-view Sensor) observations to study the seasonal evolution and variability of dust aerosols over the broader Mediterranean Sea during the period 1998-2004. Alpert and Ganor (2001) and Israelevich et al. (2002) used the Total Ozone Mapping Spectrometer (TOMS) aerosol index (AI) product to study the concentration of dust over the Middle East and the dust sources of northern Africa, respectively. The MODIS instrument, onboard both Terra and Aqua satellites, has been extensively used in studies of airborne mineral dust over the Mediterranean Basin: Barnaba and Gobbi (2004) analyzed 1-year (2001) MODIS-Terra AOD (aerosol optical depth) at $550 \mathrm{~nm}$ observations and reported on the spatial distribution and seasonal variability of aerosols, including dust, over southern Europe, with a focus over the Mediterranean region; Papayannis et al. (2005) used MODIS-Terra data synergistically with lidar measurements and dust model simulations and investigated the vertical distribution of aerosols during dust outbreaks over Greece; Kosmopoulos et al. (2008) and Papadimas et al. (2008) used MODIS-Terra and MODIS-Aqua to investigate the seasonal and interannual variability of AOD at $550 \mathrm{~nm}$ over Athens (Greece) and over the broader Mediterranean Sea, respectively; Marey et al. (2011) analyzed 10 years of MODIS data synergistically with MISR (Multi-angle Imaging SpectroRadiometer) and OMI (Ozone Monitoring Instrument), and they produced a monthly climatology of aerosols over a domain covering the Nile Delta and northeast Africa. With respect to CALIPSO, the 3-D distribution of dust and its optical properties have been studied for specific cases (e.g., Amiridis et al., 2009; Mamouri et al., 2009; Marey et al., 2011; de Meij et al., 2012; Nabat et al., 2012, 2013; Mamouri and 
Ansmann, 2015). Moreover, Winker et al. (2013) provided a 3-D global aerosol climatology from 5-year CALIPSO data, along with the global distribution of mineral dust, derived using the ratio of columnar dust AOD to total AOD. Other studies offering a global view of desert dust using CALIPSO are provided in D. Liu et al. (2008), Z. Liu et al. (2008), Adams et al. (2012), Yang et al. (2012), Tsamalis et al. (2013), Huang et al. (2015a, b) and Gkikas et al. (2016). In particular, the studies of Z. Liu et al. (2008), Yang et al. (2012) and Tsamalis et al. (2013) examined the transatlantic Saharan dust transport, focusing on the optical properties of dust, the influence of nearby clouds and the vertical distribution of the Saharan Air Layer, respectively. Huang et al. (2015a) assessed the inferred most probable heights of global dust and introduced a separation method (Huang et al., 2015b) of anthropogenic dust (produced by human activities on disturbed soils) and free-tropospheric dust using CALIPSO and MODIS products. D. Liu et al. (2008), Adams et al. (2012) and Gkikas et al. (2016) used CALIPSO observations in order to demonstrate the vertical structure of dust globally and/or above the Mediterranean. All the aforementioned studies are based on standard CALIPSO products with known limitations in accurately typing and quantifying the optical properties of pure dust (Wandinger et al., 2010; Tesche et al., 2013). The EARLINET-optimized dust CALIPSO product presented herein was used in Georgoulias et al. (2016a) to apply aerosol typing on MODIS and derive an aerosol climatology over the eastern Mediterranean.

To our knowledge, this is the first time that a 3-D puredust dataset is statistically analyzed over the area of North Africa and Europe in order to provide not only the horizontal but also the vertical patterns of Saharan dust intrusion in the Mediterranean. The study domain is from 20 to $60^{\circ} \mathrm{N}$ and from $20^{\circ} \mathrm{W}$ to $30^{\circ} \mathrm{E}$. More specifically, we investigate the 3-D inter-seasonal variation and intensity of dust transport patterns along with the interannual variations of DOD above this region. The paper is organized as follows. In Sect. 2 the CALIPSO lidar data are briefly introduced and the puredust retrieval scheme is described in detail. In Sect. 3, the main findings are presented and discussed; initially, the interseasonal variation and intensity of dust transport patterns (e.g., DOD, dust layer heights) are presented (Sect. 3.1-3.3), and the representative extinction coefficient values inside the dust plumes are derived (Sect. 3.4). In Sect. 3.5, the interannual variation of dust is examined, while our summary and concluding remarks are given in Sect. 4.

\section{Data and methodology}

\subsection{CALIPSO product}

CALIOP, flying onboard the joint NASA-CNES CALIPSO satellite, has delivered global aerosol and cloud profiles since June 2006 (Winker et al., 2009). CALIOP measures aerosol backscatter profiles at 532 and $1064 \mathrm{~nm}$, including parallel and perpendicular polarized components at $532 \mathrm{~nm}$, at high horizontal and vertical resolution. The data are processed to Level 2 (L2) products, providing aerosol and cloud backscatter and extinction coefficients at 532 and $1064 \mathrm{~nm}$ as well as the linear particle depolarization ratio at $532 \mathrm{~nm}$ (Winker et al., 2009). First, the processing algorithm separates the atmospheric scene in distinct atmospheric layers (i.e., aerosol, cloud and surface returns; Vaughan et al., 2009). Then, for each aerosol layer the algorithm determines an aerosol subtype (i.e., dust, polluted dust, clean continental, polluted continental, marine and smoke) based on a combination of information, such as the surface type, the layer integrated attenuated backscatter, the depolarization ratio at $532 \mathrm{~nm}$ and the aerosol layer height (Omar et al., 2009). The inferred subtype is used to derive the appropriate lidar ratio, which is a crucial input for the subsequent aerosol extinction retrieval (Young and Vaughan, 2009). Burton et al. (2013) showed an $80 \%$ successful detection of dust from CALIPSO, upon comparison to underflights with the HSRL (High Spectral Resolution Lidar) system of NASA. This score is considered very high for aerosol typing purposes and is attributed to the depolarization measurement capability of the CALIOP sensor. Finally, the L2 products are aggregated to a gridded monthly mean Level 3 (L3) product, providing mean profiles of extinction at $532 \mathrm{~nm}$ and mean AOD at a $2^{\circ} \times 5^{\circ}$ spatial grid resolution (Winker et al., 2013). The most recent version of the L3 product (version 3), released in October 2015, includes the correction of the AOD of cloudy scenes, the improved averaging of individual types as proposed by Amiridis et al. (2013) and D. Liu et al. (2008), and corrections of signal artifacts responsible for high and low biases as also observed in Papagiannopoulos et al. (2016).

\subsection{EARLINET-optimized CALIPSO product}

In this study, we make use of the EARLINET-optimized pure-dust extinction product, monthly averaged at a horizontal resolution of $1^{\circ} \times 1^{\circ}$, based on the methodology described in Amiridis et al. (2013). This product is a prominent outcome from the EARLINET-ESA collaboration for the LIVAS database (LIdar climatology of Vertical Aerosol Structure for space-based lidar simulation studies; Amiridis et al., 2015). Unlike the original CALIPSO L3 product of $2^{\circ} \times 5^{\circ}$ resolution, the $1^{\circ}$ resolution of LIVAS has been proven very useful in supporting studies of the same spatial resolution, specifically for the retrievals from passive satellite sensors and model evaluation studies (e.g., Popp et al., 2016; Georgoulias et al., 2016b; Tsikerdekis et al., 2017). In our methodology, the pure-dust backscatter coefficient $\left(\beta_{\mathrm{d}}\right)$ is decoupled from the total aerosol backscatter $\left(\beta_{\mathrm{p}}\right)$ based on depolarization measurements $\left(\delta_{\mathrm{p}}\right)$, assuming a particle depolarization ratio value for pure dust $\left(\delta_{\mathrm{d}}\right)$ equal to 0.31 (Tesche et al., 2009). Typical dust $\delta_{\mathrm{d}}$ values measured with lidars in field campaigns around the globe are generally consistent with this 
value, showing little variation independent of the source region (e.g., Sakai et al., 2000; Z. Liu et al., 2008; Freudenthaler et al., 2009; Burton et al., 2013; Groß et al., 2011, 2013, 2015; Illingworth et al., 2015). During the SAMUM (Saharan Mineral Dust Experiment) 1 and 2 campaigns, Saharan dust $\delta_{\text {nd }}$ values varied between 0.27 and 0.35 at $532 \mathrm{~nm}$ (Ansmann et al., 2011), introducing a $4 \%$ error in our calculations for the dust separated backscatter values. Using this separation technique, we avoid relying on the polluted dust and dust aerosol types used in CALIPSO and, thus, eliminate possible misclassifications found in the CALIPSO L2 product (Burton et al., 2013). A final correction is related to the particle linear depolarization ratio, which is recalculated from L2 perpendicular and total backscatter profiles, to improve the accuracy compared to the original CALIPSO L2 version 3 product, affected by a known bug (Tesche et al., 2013; Amiridis et al., 2013).

The quality control procedures and filtering criteria applied in the dataset are summarized in Table 1. In brief, CALIPSO L3 version 3 screening procedure is followed (Winker et al., 2013; CALIPSO L3-V3, 2015), and additional filters are incorporated to ensure the use of only cloud-free profiles. The additional methodology is as follows:

a. We remove all profiles with cloud features anywhere in the column.

b. We remove all profiles which fulfil the L3 CALIPSO "CAD score" or "Cirrus fringes" filters (see also Table 1).

The pure-dust extinction coefficient is computed using a lidar ratio of $55 \mathrm{sr}$ instead of the $40 \mathrm{sr}$ used in the CALIPSO product (Omar et al., 2009; Lopes et al., 2013). This value is representative of dust over Europe, mainly originating from northwest Africa, as measured in coordinated CALIPSO-EARLINET measurements (Pappalardo et al., 2010; Wandinger et al., 2011), and is in excellent agreement with recent studies of dust measurements both near the source (Tesche et al., 2009; Veselovskii et al., 2016) and during long-range transport (Preißler et al., 2012; Kanitz et al., 2013; Groß et al., 2015; Baars et al., 2016; Papagiannopoulos et al., 2016). The individual backscatter coefficient profiles at $532 \mathrm{~nm}$ are aggregated at a horizontal spatial resolution of $1^{\circ} \times 1^{\circ}$ and a vertical resolution of $60 \mathrm{~m}$ from -0.5 to $20.2 \mathrm{~km}$ and $180 \mathrm{~m}$ from 20.2 to $30.1 \mathrm{~km}$. This product height is referenced to above sea level (a.s.l.) altitude.

\subsection{Climatological vs. Conditional dust product}

In this study, we calculate two separate dust products - the climatological and the conditional.

The climatological dust product is based on Amiridis et al. (2013), with a value of $0 \mathrm{~km}^{-1}$ assigned to the non-dust aerosol types when averaging within a cell. This product, hereinafter, is referred to as the Climatological Dust Extinction (Clim-DE), and the corresponding AOD as Dust AOD
(DOD), and is presented and discussed in Sect. 3.1-3.3. As already discussed in the introduction, this product has been evaluated against AERONET data and is in very good agreement with collocated measurements over the Sahara and Europe (Amiridis et al., 2013). The averaging methodology has been adapted by the L3-V3 CALIPSO product.

The conditional dust product is derived from averaging the CALIPSO dust extinction coefficients where dust is present, ignoring non-dust observations in the area. In particular, the clear air and non-dust aerosol types detected in the cell are ignored (set as NaN values when averaging). This product is referred to as the Conditional Dust Extinction coefficient product (Con-DE) and is presented and discussed in Sect. 3.4.

The two products can be used for different applications. For example, Clim-DE is representative of the dust contribution to the total aerosol load and can be valuable in climatological studies. Moreover, the near-surface DOD helps to estimate the natural aerosol contribution in the total aerosol load close to the surface for air-quality applications. The Con-DE product, on the other hand, provides a measure of the intensity of the dust plumes.

\subsection{Dust product uncertainties}

The sources of uncertainties for the pure-dust product are discussed in this section. CALIOP is able to detect aerosol layers with AOD $>0.005$ and $\beta>0.25 \mathrm{Mm}^{-1} \mathrm{sr}^{-1}$ (Winker et al., 2009). The uncertainty estimation of particulate backscatter, extinction and AOD retrievals reported in the CALIPSO Level 2, version 3 data release, are based on the simplified assumption that all the uncertainties are random, uncorrelated and produce no biases (Young, 2010). More specifically, ignoring multiple scattering, the errors in the layer optical depth calculations typically arise from three main sources: (a) signal-to-noise ratio within a layer, (b) calibration accuracy and (c) the accuracy of the lidar ratio used for the extinction retrieval. The lidar ratio uncertainty is the dominant contributor to the total uncertainties, and the relative error in the layer optical depth is always at least as large as the relative error in the lidar ratio of the layer and grows as the solution propagates through the layer (CALIPSO L2V3, 2010). In our dataset the typical uncertainties in the CALIPSO Level 2 version 3 product are between 30 and $100 \%$ for the AOD, between 30 and $160 \%$ for the aerosol backscatter and extinction coefficient, and $>100 \%$ for the particle depolarization ratio.

Several studies report that CALIPSO underestimates the columnar AOD due to undetected aerosol in the free atmosphere. For instance, Rogers et al. (2014) report a $\sim 0.02$ AOD CALIPSO underestimation, when compared to collocated airborne HSRL measurements over the North American and Caribbean regions at night. In their data, the dust layers were primarily non-opaque with extinction less than $1 \mathrm{~km}^{-1}$, so there were negligible multiple scattering effects. 
Table 1. Quality control procedures and filtering applied in CALIPSO data.

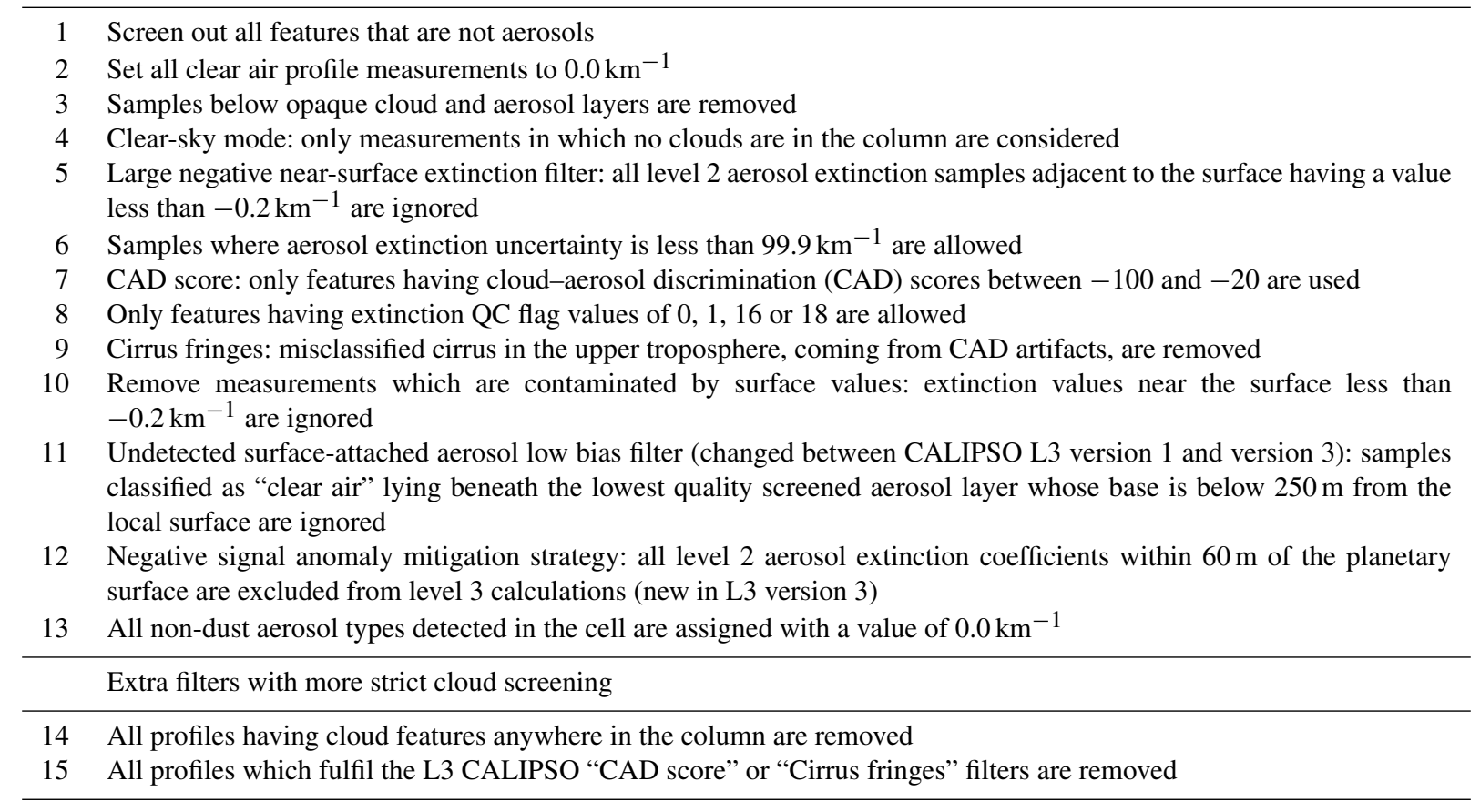

These detection limits and uncertainties of CALIPSO products are propagated to the dust product presented here.

As already described, the EARLINET-optimized CALIPSO dust product is derived using the depolarizationbased separation method, coupled with the selection of a uniform climatological LR value. These steps introduce uncertainties in the pure-dust product. In particular, the uncertainty in the selection of the representative LR $(55 \pm 11)$ is $20 \%$ for the study area (e.g., Wandinger et al., 2010; Baars et al., 2016, and references within). This uncertainty in LR is less than half of the uncertainty of the generic LR in the CALIPSO version 3 product $(40 \pm 20$ for dust layers and $55 \pm 22$ for polluted dust layers). As already addressed in several studies (e.g., Wandinger et al., 2010; Schuster et al., 2012; Amiridis et al., 2013), the CALIPSO V3 dust extinction coefficient and AOD values are about $30 \%$ lower than those obtained from collocated ground-based Raman lidar retrievals due to the low LR used in the CALIPSO aerosol retrievals. Amiridis et al. (2013) applied the EARLINET LR for the pure-dust CALIPSO cases above North Africa and Europe and compared with synchronous and collocated AERONET measurements. The results showed an absolute bias on the AOD of the order of -0.03 , improving on the statistically significant biases of the order of -0.10 reported in the literature for the original CALIPSO product. The bias of -0.03 is similar to the low bias of CALIPSO's column AOD due to undetected aerosol layers. In Kim et al. (2017), they found a global mean undetected layer AOD of $0.0031 \pm 0.052$ by comparing 2 years of CALIPSO (L1-V4) and MODIS AODs.
Regarding the error induced from the application of the dust separation method, this might be due to the selection of the particle depolarization ratio of dust and the other aerosol types (marine, anthropogenic or smoke). Tesche et al. (2009, 2011), and Ansmann et al. (2012) estimated that the uncertainty in dust related backscatter coefficients is $15-20 \%$ in well-detected dessert dust layers and $20-30 \%$ in less pronounces aerosol layers. Moreover, we have calculated that the uncertainty of the dust occurrences presented in Sect. 3.1 ("\% dust/used overpasses"), might be up to $8 \%$ in latitude away from the sources, which is induced from the error in the selection of the $\delta_{\text {nd }}$ value $(0.03 \pm 0.04)$. Finally, an uncertainty induced in the dust product presented in this work originates from the CALIPSO subtype selection algorithm. In this version of our product, both dust and polluted dust observations are considered polluted dust and the pure-dust component is separated using the dust separation method. The other aerosol layers, which are characterized as clean marine (CM), smoke (S), polluted continental (PC) or clean continental (CC), are considered to be cases clear of dust and are not tested for a dust component. This introduces negligible error in our analysis and is expected to induce a negative bias in the parameter $\%$ dust/used overpasses less than $8 \%$, mainly in areas above sea. In general, for Clim-DE and Cond-DE products, the uncertainty of the dust extinction values close to the surface and at high latitudes is $<54 \%$. At high altitudes and for latitudes up to $45^{\circ} \mathrm{N}$, the uncertainty of the values is $<20 \%$. Nevertheless, the standard deviation of the climatological products, coming from the natural variability of the dust events, may exceed to a large extent the 
uncertainty of the retrieval, reaching values as high as 100 and $200 \%$.

In the latest release of the CALIPSO Level 2 version 4 product (CALIPSO L2-V4, 2016), based on the CALIPSO team announcement, the accuracy of the original CALIPSO product is increased and the uncertainty is reduced. This version is based on a revised calibration approach which leads to an increase in the total attenuated backscatter coefficients by $\sim 3 \%$ overall as compared to the version 3 values (CALIPSO L1-V4, 2016). Several bugs are fixed and a major overhaul of the aerosol subtyping algorithms along with revisions on the lidar ratio selections is applied.

\subsection{Additional satellite and model dataset}

s The sixth version level-3 MODIS-Terra is a $1^{\circ} \times 1^{\circ}$ gridded aerosol dataset that is acquired from the NASA Giovanni system (https://giovanni.sci.gsfc.nasa.gov/giovanni/). In the current study the MODIS combined dataset of aerosol optical depth (that takes into account the dark target, dark surface, and deep blue, bright surface, measurements) was used for the period from 2007 to 2015 (Sayer et al., 2014). Over the Mediterranean, MODIS-Terra v6 was evaluated against 23 AERONET stations and was proven to score better than its predecessor MODIS-Terra v5 (Georgoulias et al., 2016b).

The MACC global dataset is a reanalysis product based on the Integrated Forecast System (IFS) of the European Centre for Medium-Range Weather Forecast (ECMWF) coupled with the chemistry transport model MOZART-3 (Kinnison et al., 2007). The horizontal resolution of the model is $80 \mathrm{~km}$, and it uses 60 vertical levels from the surface up to $0.1 \mathrm{hPa}$. MACC has been used in numerous gas phase and particulate matter studies (Innes et al., 2013; Katragkou et., 2015; Eskes et al., 2015; Flemming et al., 2015; Cuevas et al., 2015; Georgoulias et al., 2017). The dust optical depth data used in this study covers the period 2007-2012, and all MACC data are open to the public (http://apps.ecmwf.int/datasets/data/ macc-reanalysis/levtype $=\mathrm{sfc} /$ ). $\mathrm{RegCM} 4$ is an open source, area-limited, sigma-p vertical coordinated regional climate model (Giorgi et al., 2012) based on the hydrostatic core of the Penn State University/National Center for Atmospheric Research (PSU/NCAR) mesoscale model (MM5; Grell et al., 1994). The simulation used in the current study is part of a previous research where the dust optical depth of the model was evaluated against the dust climatological product of this work, after it was fully spatially and temporally collocated with the exact flyby of CALIPSO (Tsikerdekis et al., 2017). The simulation covers the period from 2007 to 2014 with a horizontal resolution of $50 \mathrm{~km}$ and 18 vertical sigma-p levels.

\section{Results and discussion}

In Sect. 3.1-3.4, we examine the inter-seasonal variation and intensity of dust transport patterns, from 2007 to 2015, for the domain $20^{\circ} \mathrm{W}$ to $30^{\circ} \mathrm{E}$ and 20 to $60^{\circ} \mathrm{N}$. In Sect. 3.1 we provide the average climatological state of the seasonal dust distribution at a spatial resolution of $1^{\circ} \times 1^{\circ}$. In Sect. 3.2 we give information on dust layer heights. In Sect. 3.3, we illustrate the mean climatological vertical structure of dust reaching Europe. To achieve that, the area of study is separated into five longitudinal zones with a step of $10^{\circ}$. In Sect. 3.4, we illustrate the vertical intensity of the dust plumes, using again longitudinal zone maps. Finally, in Sect. 3.5, we examine the interannual variation of dust.

\subsection{Horizontal dust distribution}

In this section, we provide the average climatological state of the seasonal horizontal dust distribution derived from the CALIPSO dust product at a spatial resolution of $1^{\circ} \times 1^{\circ}$ for the domain of North Africa and Europe. The seasonal grouping used in this study is as follows: from January to March (JFM), from April to June (AMJ), from July to September (JAS) and from October to December (OND). In our study region, March and October are considered transition months for Saharan dust advection (e.g., Ganor, 1994; Guirado et al., 2014). This grouping is based on the dominant patterns revealed from the maps of monthly mean DODs (not shown): the events during February-March and OctoberNovember, although rarer, are usually more intense than those of the other months. This is further supported from a 10-year (2001-2011) analysis of African dust outbreak $\mathrm{PM}_{10}$ (particulate matter with aerodynamic diameter lower than $10 \mu \mathrm{m}$ ) observations over the Mediterranean Basin (Pey et al., 2013).

Figure 1 shows the geographical distribution of dust occurrences (Fig. 1a, c, e, g) and the corresponding mean DOD values for each season (Fig. 1b, d, f, h). In order to provide a more quantitative representation of the dataset, the domain is aggregated in six areas over the study region. The main results and statistical parameters are provided in Table 2, and a map with the domains is shown in Fig. 2. In particular, the information provided is the mean and standard deviation of the DOD, the maximum values along with the 95th percentile in parenthesis, the layer's center of mass and top height along with their standard deviations (these parameters are discussed in the next section), the percentage of the observations with DOD greater than zero in the cloud-free observations, the percentage of the cloud-free occurrences in the total observations provided by the CALIPSO product (with $100 \%$ as unity) and each domain's geographic extent.

Table 2 shows the impact of cloud contamination in our dataset. During AMJ, JAS and OND, more than $80 \%$ of the total observations are cloud free above North Africa. The percentage is the same above the central-eastern Mediterranean 


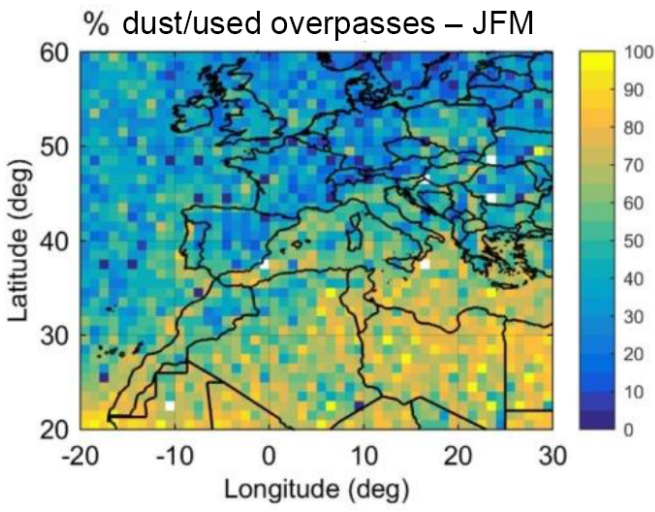

(a)

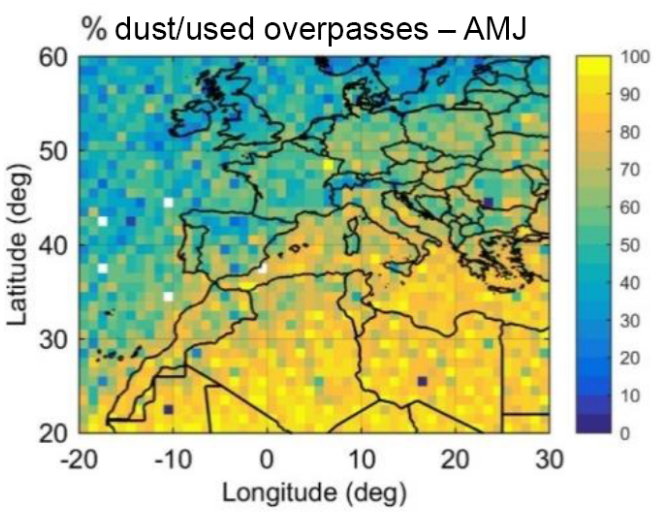

(b)

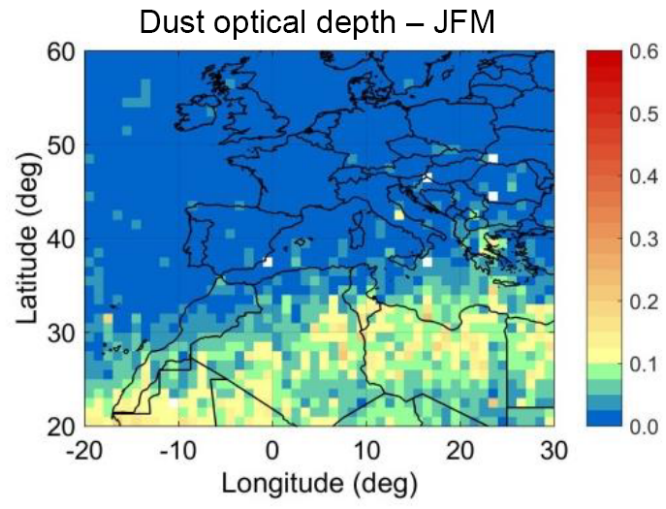

(c) $\%$ dust/used overpasses - JAS

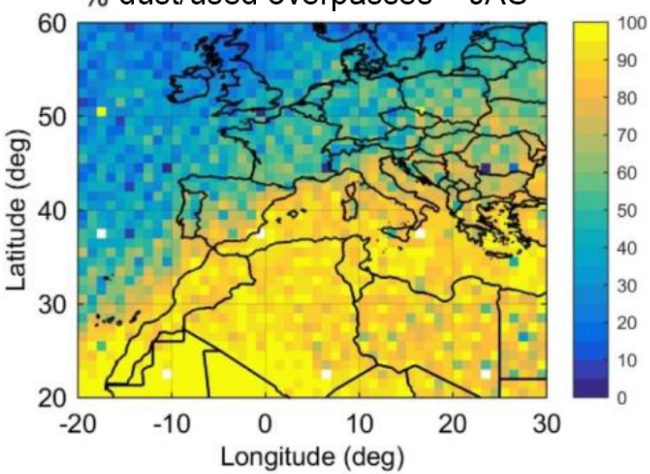

(d)

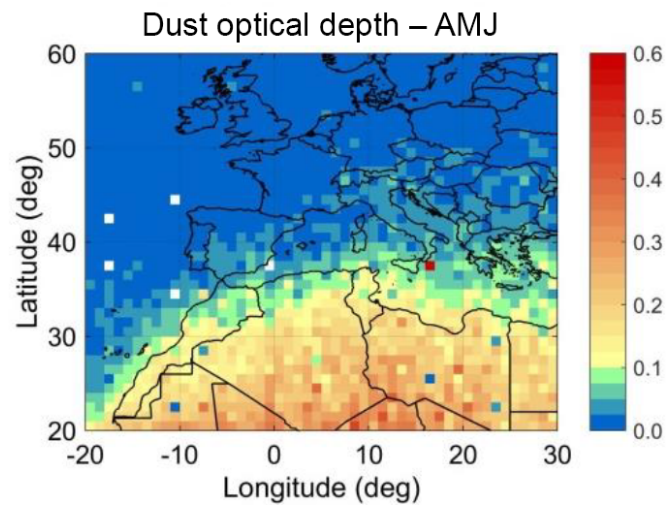

(e) $\%$ dust/used overpasses - OND

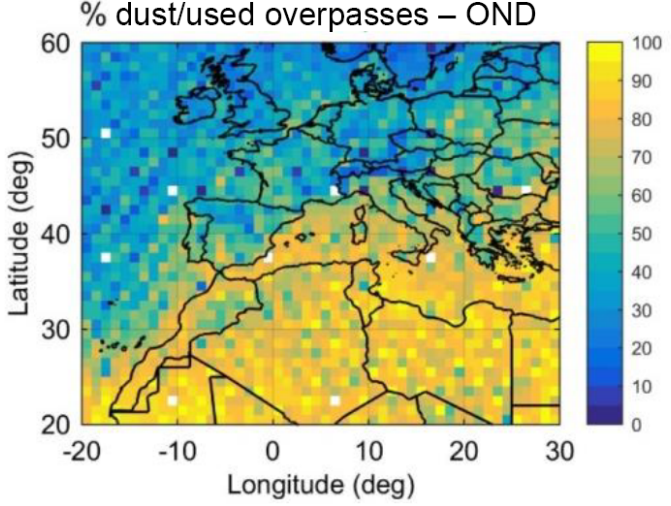

(f)
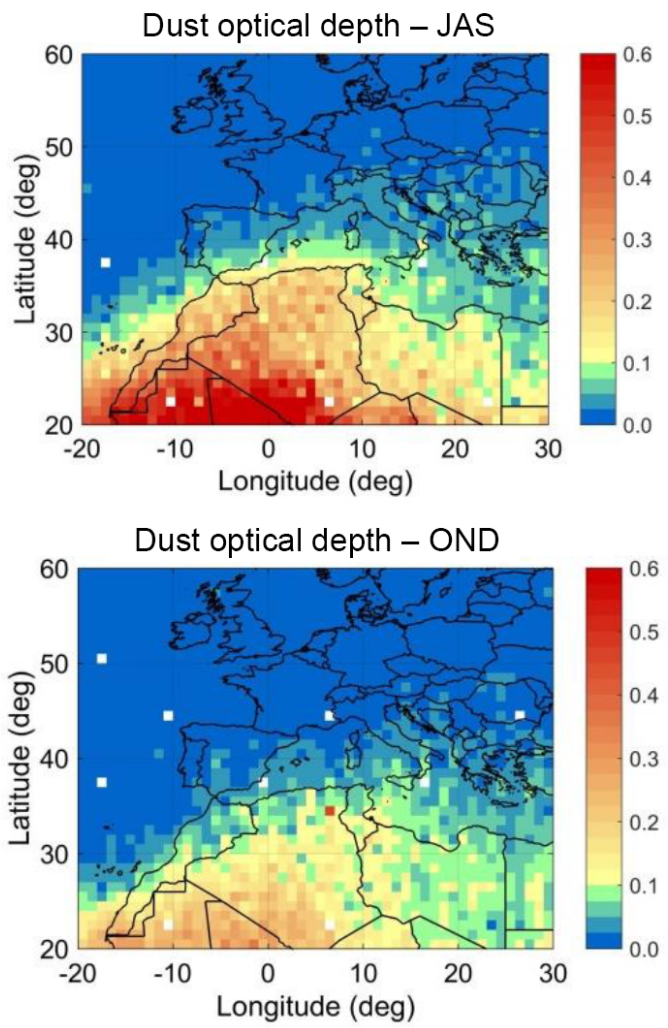

Figure 1. Geographical distribution of the seasonal dust occurrences (a, c, e, d) and the mean DOD values (b, d, f, h) for the 3-month averages: January-March (a, b), April-June (c, d), July-September (e, f), and October-November (g, h), and the domain between $20^{\circ}$ W$30^{\circ} \mathrm{E}$ and $20-60^{\circ} \mathrm{N}$ for the period 2007-2015, measured with the CALIPSO climatological dust product. 
Table 2. Regional statistics on mean dust optical depth, max values, dust layer center of mass (CoM) and top height (TH) (a.s.l.), ratio of dust observations to cloud-free observations, ratio of cloud-free observations to total observations and domain boundaries.

\begin{tabular}{|c|c|c|c|c|c|c|c|}
\hline & DOD Mean \pm SD & DOD Max Vals. (Perc. 95\%) & $\mathrm{CoM} \pm \mathrm{SD}$ & Top Height \pm SD & $\mathrm{Nr}$ Dst in $\mathrm{Nr}$ cl-free & $\mathrm{Nr}$ cl-free in $\mathrm{Nr}$ obs. & Domain \\
\hline \multicolumn{8}{|c|}{ NE Africa } \\
\hline JFM & $0.11 \pm 0.17$ & $2.19(0.42)$ & $1.5 \pm 1.2$ & $2.6 \pm 1.8$ & 0.72 & 0.84 & \multirow{4}{*}{$\begin{array}{l}{\left[10^{\circ} \mathrm{E}, 30^{\circ} \mathrm{E}\right]} \\
{\left[20^{\circ} \mathrm{N}, 30^{\circ} \mathrm{N}\right]}\end{array}$} \\
\hline AMJ & $0.26 \pm 0.26$ & $3.09(0.73)$ & $2.4 \pm 1.1$ & $4.2 \pm 1.7$ & 0.86 & 0.86 & \\
\hline JAS & $0.18 \pm 0.21$ & $2.63(0.56)$ & $2.3 \pm 1.0$ & $4.0 \pm 1.4$ & 0.84 & 0.93 & \\
\hline OND & $0.11 \pm 0.14$ & $2.93(0.34)$ & $1.9 \pm 0.9$ & $3.3 \pm 1.4$ & 0.81 & 0.93 & \\
\hline \multicolumn{8}{|c|}{ NW Africa } \\
\hline JFM & $0.13 \pm 0.18$ & $1.86(0.47)$ & $1.5 \pm 1.3$ & $2.4 \pm 1.8$ & 0.67 & 0.82 & \multirow{4}{*}{$\begin{array}{l}{\left[10^{\circ} \mathrm{W}, 10^{\circ} \mathrm{E}\right]} \\
{\left[20^{\circ} \mathrm{N}, 35^{\circ} \mathrm{N}\right]}\end{array}$} \\
\hline AMJ & $0.26 \pm 0.26$ & $2.31(0.75)$ & $2.2 \pm 1.2$ & $3.8 \pm 1.6$ & 0.86 & 0.83 & \\
\hline JAS & $0.43 \pm 0.39$ & $3.03(1.20)$ & $2.9 \pm 1.0$ & $5.1 \pm 1.3$ & 0.94 & 0.88 & \\
\hline OND & $0.22 \pm 0.26$ & $2.59(0.71)$ & $2.2 \pm 1.0$ & $3.9 \pm 1.6$ & 0.82 & 0.81 & \\
\hline \multicolumn{8}{|c|}{ C-E Med. } \\
\hline JFM & $0.09 \pm 0.18$ & $1.62(0.41)$ & $1.3 \pm 1.4$ & $2.3 \pm 1.9$ & 0.69 & 0.70 & \multirow{4}{*}{$\begin{array}{l}{\left[10^{\circ} \mathrm{E}, 30^{\circ} \mathrm{E}\right]} \\
{\left[30^{\circ} \mathrm{N}, 45^{\circ} \mathrm{N}\right]}\end{array}$} \\
\hline AMJ & $0.12 \pm 0.20$ & $2.74(0.51)$ & $1.8 \pm 1.5$ & $3.2 \pm 2.1$ & 0.82 & 0.76 & \\
\hline JAS & $0.08 \pm 0.12$ & $1.80(0.33)$ & $1.6 \pm 1.1$ & $3.0 \pm 1.7$ & 0.89 & 0.96 & \\
\hline OND & $0.08 \pm 0.11$ & $1.55(0.31)$ & $1.4 \pm 1.1$ & $2.7 \pm 1.6$ & 0.82 & 0.80 & \\
\hline \multicolumn{8}{|c|}{ C-W Med. } \\
\hline JFM & $0.03 \pm 0.06$ & $1.09(0.11)$ & $1.3 \pm 1.6$ & $2.0 \pm 1.9$ & 0.49 & 0.57 & \multirow{4}{*}{$\begin{array}{l}{\left[10^{\circ} \mathrm{W}, 10^{\circ} \mathrm{E}\right]} \\
{\left[35^{\circ} \mathrm{N}, 45^{\circ} \mathrm{N}\right]}\end{array}$} \\
\hline AMJ & $0.05 \pm 0.10$ & $1.35(0.25)$ & $1.8 \pm 1.6$ & $2.9 \pm 2.2$ & 0.65 & 0.61 & \\
\hline JAS & $0.09 \pm 0.14$ & $2.33(0.36)$ & $1.9 \pm 1.2$ & $3.3 \pm 1.8$ & 0.75 & 0.80 & \\
\hline OND & $0.05 \pm 0.09$ & $1.62(0.20)$ & $1.3 \pm 1.2$ & $2.3 \pm 1.6$ & 0.63 & 0.64 & \\
\hline \multicolumn{8}{|c|}{ NE Europe } \\
\hline JFM & $0.025 \pm 0.055$ & $0.97(0.11)$ & $1.2 \pm 1.4$ & $1.7 \pm 1.7$ & 0.37 & 0.28 & \multirow{4}{*}{$\begin{array}{l}{\left[10^{\circ} \mathrm{E}, 30^{\circ} \mathrm{E}\right]} \\
{\left[45^{\circ} \mathrm{N}, 60^{\circ} \mathrm{N}\right]}\end{array}$} \\
\hline AMJ & $0.033 \pm 0.062$ & $1.61(0.12)$ & $1.6 \pm 1.2$ & $2.5 \pm 1.6$ & 0.61 & 0.47 & \\
\hline JAS & $0.032 \pm 0.045$ & $0.90(0.11)$ & $1.6 \pm 1.1$ & $2.7 \pm 1.4$ & 0.60 & 0.58 & \\
\hline OND & $0.023 \pm 0.043$ & $0.50(0.09)$ & $1.2 \pm 1.0$ & $1.9 \pm 1.4$ & 0.49 & 0.43 & \\
\hline \multicolumn{8}{|c|}{ NW Europe } \\
\hline JFM & $0.015 \pm 0.033$ & $0.47(0.06)$ & $1.2 \pm 1.6$ & $1.7 \pm 1.7$ & 0.36 & 0.36 & \multirow{4}{*}{$\begin{array}{l}{\left[10^{\circ} \mathrm{W}, 10^{\circ} \mathrm{E}\right]} \\
{\left[45^{\circ} \mathrm{N}, 60^{\circ} \mathrm{N}\right]}\end{array}$} \\
\hline AMJ & $0.023 \pm 0.037$ & $0.73(0.08)$ & $1.5 \pm 1.6$ & $2.2 \pm 1.9$ & 0.52 & 0.47 & \\
\hline JAS & $0.022 \pm 0.042$ & $0.93(0.08)$ & $1.4 \pm 1.5$ & $2.1 \pm 1.7$ & 0.43 & 0.52 & \\
\hline OND & $0.018 \pm 0.035$ & $0.57(0.07)$ & $1.1 \pm 1.2$ & $1.7 \pm 1.4$ & 0.40 & 0.44 & \\
\hline
\end{tabular}

(C-E Med.), whereas above the central-western Mediterranean $(\mathrm{C}-\mathrm{W}$ Med.) is approximately $60-80 \%$. With increasing latitude, the cloud-free sampling is reduced to percentages of $\sim 40-60 \%$ in latitudes greater than $45^{\circ} \mathrm{N}$. During JFM, cloudy conditions restrict our dataset in the greatest extent. During the same period, the cloud-free cases used represent $\sim 80 \%$ of the total observations above North Africa, approximately $60-70 \%$ above the Mediterranean and $\sim 30 \%$ in the domain between 45 and $60^{\circ} \mathrm{N}$. In the areas (and seasons) where clouds do not dominate (e.g., $70 \%$ clearsky conditions), our cloud-free product is considered representative of the dust distribution. In areas where cloudy skies dominate (e.g., $30 \%$ clear-sky conditions), the clearsky CALIPSO profiles cannot be considered as representative of all meteorological conditions, so the results should be used with caution.

Based on Fig. 1 and Table 2, the overall percentages of dust occurrences and mean DOD values are greater during summer and spring months. During autumn and winter the emission and transport of dust towards Europe is suppressed due to the more effective removal processes and due to the atmospheric dynamics favoring the transport of dust towards the Atlantic (e.g., Israelevich et al., 2002; Schepanski et al., 2009). More specifically, during JFM (Fig. 1a, b) limited dust activity is observed almost uniformly over the Sahara desert. The DOD remains below 0.13 roughly over the entire study domain, with $75 \%$ of the observations having DODs $<0.17$, $95 \%$ of the observation having DODs $<0.5$ and extreme values with DODs $>2$. The dust occurrences decrease with latitude and the presence of dust is approximately $70 \%$ over Africa and the Mediterranean region and decreases to lower than $50 \%$ over northern Europe. The most affected area during these months is eastern Mediterranean. The cyclone formation over the central Mediterranean, which is affected by mid-latitude depressions generated either in the Atlantic Ocean or in northwestern Europe (e.g., Trigo et al., 1999; Maheras et al., 2001), results in the transportation of dust from the Libyan Desert towards the Balkans, leading to dust occurrences up to $70 \%$ (Fig. 1a) along with mean seasonal DODs of $0.1-0.2$ (Fig. 1b). In the domains between 10 and $30^{\circ} \mathrm{E}$ and $30-40^{\circ} \mathrm{N}, 5 \%$ of dust events are observed with DODs $>0.41,1 \%$ with DODs $>0.95$ and extreme observations with DODs are up to 1.6. Similar mean values have been reported in the literature for this period, along with 


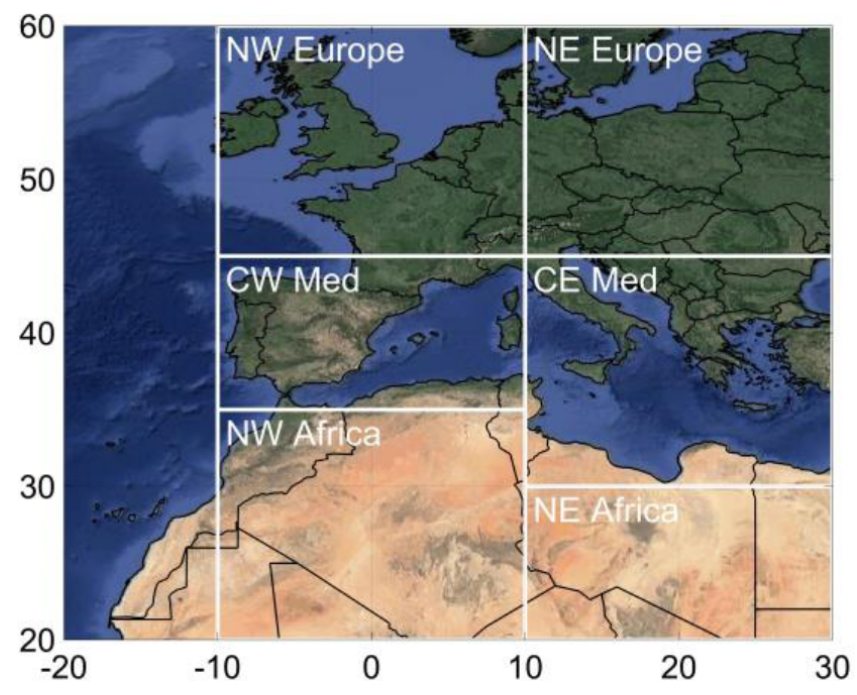

Figure 2. The six domains of the regional statistics provided on Tables 2 and 3 .

extreme events characterized by AOD values higher than 1 (Gerasopoulos et al., 2011). Moving northward, mean DOD tends to decrease due to the increasing distance from the major dust sources and also due to higher precipitation at the northern parts of the study region that efficiently removes dust from the atmosphere (e.g., Moulin et al., 1998; Marrioti et al., 2002).

During AMJ (Fig. 1c, d) dust production occurs over the entire Saharan desert, with mean DOD values of $0.26 \pm 0.26$ and occurrences of $86 \%$, uniformly at latitudes between $20^{\circ} \mathrm{N}$ and $30^{\circ} \mathrm{N}$. The activated dust sources are located in the broad "dust belt" and are usually associated with topographical lows in the arid regions and with the intermountain basins (Prospero et al., 2002). The arrival of mid-latitude extratropical cyclone systems from the Atlantic Ocean as well as cyclogenesis at the Gulf of Genoa and/or at the northern African coast favors dust transport over the central and eastern Mediterranean. Mean DOD over these areas reaches values of $0.12 \pm 0.20$ (Fig. 1d) and extreme observations observed with DODs up to 2.74. Dust is also present over central and northern Europe with mean DOD up to $0.033 \pm 0.062$ and occurrence percentages up to $61 \%$ (Fig. 1c; Table 2), revealing that dust particles can be transported far away from their sources under favorable meteorological conditions.

During JAS (Fig. 1e, f), intense dust activity is prominently shifted to the western part of the Sahara where dust occurrences are $>90 \%$ and mean DOD near the sources is up to 0.6 (Fig. 1f). In the domain between $10^{\circ} \mathrm{W}-00^{\circ}$ and 20 $35^{\circ} \mathrm{N}$, the mean DOD is 0.43 , with $25 \%$ of the dust observations having DODs $>0.69,5 \%>1.2$ and the extreme DODs up to 3 (Table 2). The migration of the ITCZ (Intertropical Convergence Zone) towards higher latitudes and the dominance of trade wind patterns (easterlies) benefit the trans- portation of dust towards the Atlantic Ocean as seen also by the westward plumes in Fig. 1e and f. In the same period, increased dust occurrences $(83 \%)$ are also found over the western Mediterranean and South Italy. In the domain between $10^{\circ} \mathrm{W}-00^{\circ}$ and $35-45^{\circ} \mathrm{N}$, the mean DODs are $0.09 \pm 0.14$ with $5 \%$ of the dust observations having DODs $>0.55$ and extreme DODs up to 2.3 .

During OND dust activity is significantly suppressed (Fig. 1g) except from the southwest desert areas close to the Sahel where mean DOD lies in the range 0.2-0.3 (Fig. 1h). In the domain between $10^{\circ} \mathrm{W}-00^{\circ}$ and $20-30^{\circ} \mathrm{N}$, the mean DODs are $0.43 \pm 0.39$ and extreme DODs up to 3 (Table 2).

In order to provide a more informative representation of the dust product, we performed a comparison with MODIS AOD for the same period, the dust optical depth of the MACC reanalysis for the period 2007-2012 and a RegCM4 simulation for the period 2007-2014 (Fig. 3). MODIS provides the AOD for all natural and anthropogenic aerosol types. As a result the MODIS average value for the whole period and domain $(0.267)$ is $281 \%$ bigger than our product $(0.095 \pm 0.04)$. It is noted though that the values between the two satellite products are very similar over the Sahara desert. On the contrary, the corresponding average dust optical depth values of MACC (0.100) and RegCM4 simulations $(0.104)$ consider only dust and are in better agreement with our product, with lower values by 5 and $8.6 \%$, respectively. The $95 \%$ confidence interval of the mean for MACC is between 0.092 and 0.108, and for RegCM4 it is between 0.099 and 0.108. Considering these ranges, the discrepancies between the CALIPSO dust product and the two models are within the combined uncertainty.

Dust optical depth is overestimated over Europe and the Mediterranean by MACC and RegCM4 simulations compared to our product, in all seasons and especially in the hot periods of AMJ and JJA. The reasons of these discrepancies have to be further studied.

\subsection{Vertical dust distribution}

CALIPSO offers the ability to assess the vertical distribution of dust from space. To facilitate the investigation of the vertical characteristics of dust, two parameters are introduced the dust top height (TH) and the dust center of mass height (CoM) (Mona et al., 2006, 2014; Binietoglou et al., 2015). $\mathrm{TH}$ is defined as the height corresponding to the altitude with $98 \%$ of the dust extinction below it. CoM is the extinctionweighted altitude given by the formula

$$
\operatorname{CoM}=\frac{\int_{z_{\mathrm{t}}}^{z_{\mathrm{b}}} z a(z) \mathrm{d} z}{\int_{z_{\mathrm{t}}}^{z_{\mathrm{b}}} a(z) \mathrm{d} z},
$$

where $z_{\mathrm{b}}$ and $z_{\mathrm{t}}$ are the base and top altitude of the dust feature, respectively, and $\alpha$ denotes the dust extinction coeffi- 


\section{CALIPSO - DOD}
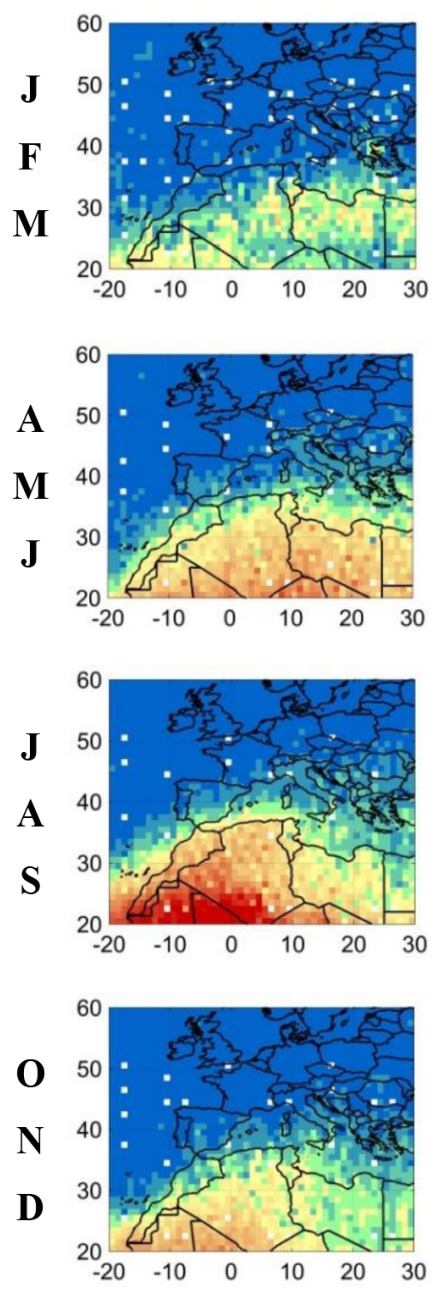

MODIS - AOD
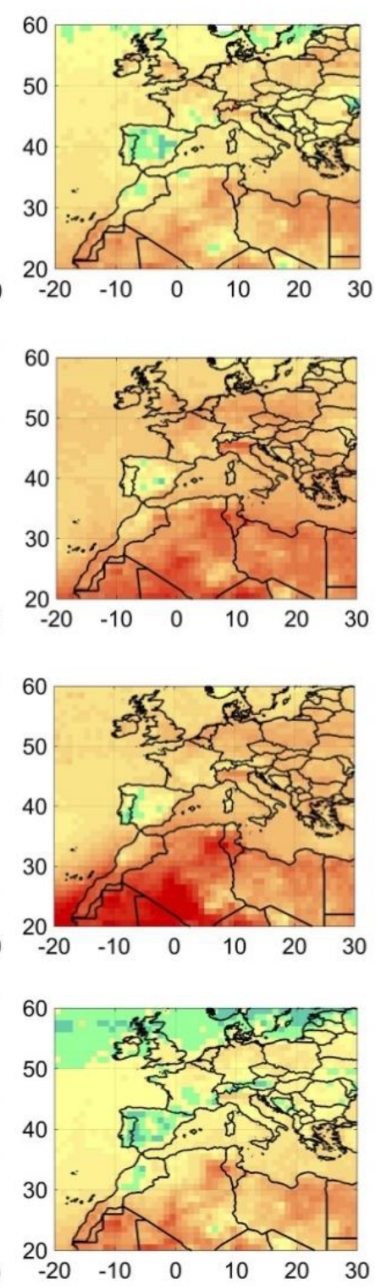

MACC - DOD

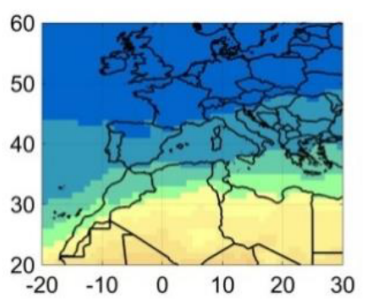

\section{RegCM4-DOD}
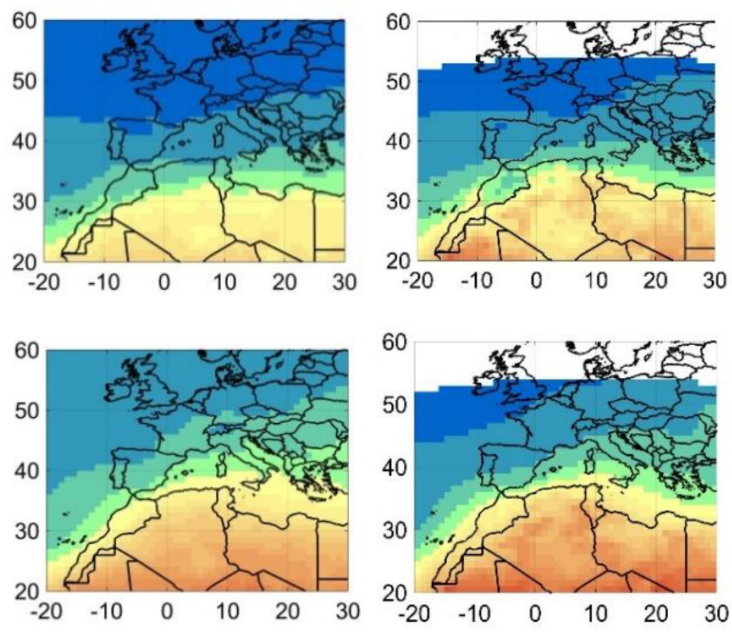

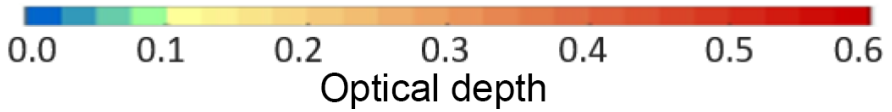
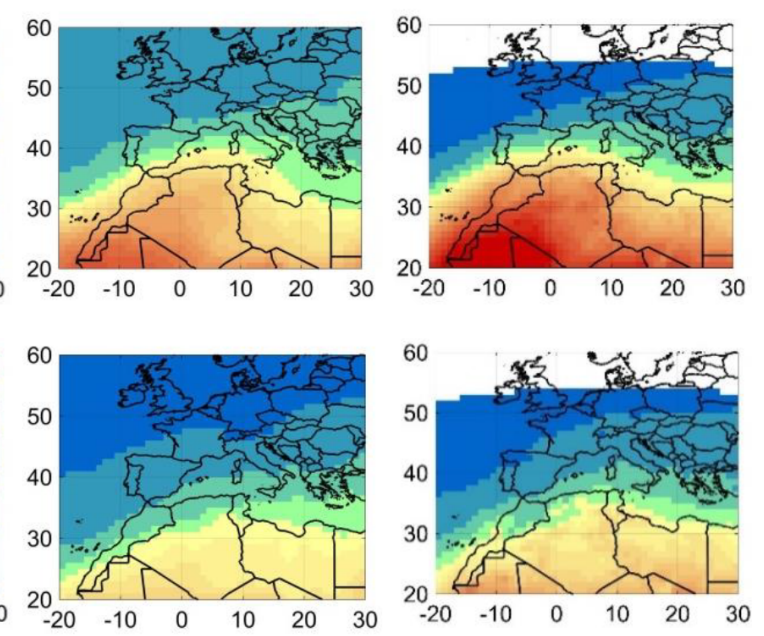

Figure 3. Comparison of the seasonal spatial distribution of the optical depth as received by (first column) pure-dust CALIPSO DOD product, (second column) MODIS AOD product, (third column) MACC reanalysis DOD product, (fourth column) RegCM4-simulated DOD product.

cient at altitude z. CoM provides a measure of the altitude where most of the dust load is located. This parameter is considered ideal for comparisons with aerosol layer height retrievals from passive remote sensing (e.g., IASI, GOME-2A, Sentinel5P and the future Sentinel-4 and Sentinel-5 missions; Ingmann et al., 2012), since these retrievals are sensitive to the location of the dust mass maximum within the layer (e.g., TROPOMI Aerosol Layer Height product; Sanders et al., 2015).

Figure 4 shows the spatial distribution of $\mathrm{TH}$ and $\mathrm{CoM}$ for the four seasons. In Table 2, the TH and CoM values above surface elevation (a.s.e.) are accompanied with their standard deviations providing an indication of the variability of the dust heights in the atmosphere of the study area. During JFM dust resides in general below $3 \mathrm{~km}$ a.s.e. over land, with CoM at about $1.3 \pm 1.6 \mathrm{~km}$ a.s.e. (Fig. $4 \mathrm{a}, \mathrm{b}$ ). Over the sea, several transport paths are discernible especially over the eastern Mediterranean, with dust tops traveling at $2.3 \pm 1.9 \mathrm{~km}$ a.s.e. Over the eastern parts of the Sahara during AMJ, TH and CoM are up to $4.2 \pm 1.7 \mathrm{~km}$ and $2.4 \pm 1.1 \mathrm{~km}$ a.s.e., respectively. Over the Mediterranean Sea and southern Europe, dust tops extend at $\sim 2-3.5 \mathrm{~km}$ and $\mathrm{CoM}$ is $\sim 1-2 \mathrm{~km}$ a.s.e., with the central and eastern Mediterranean having the most elevated plumes (Fig. 4c, d). The latitudinal slope of CoM denotes the latitudinal transport of dust during AMJ from south to north. The highest TH values $(>4.5 \mathrm{~km})$ are found during the warm period (JAS) over northwestern Africa and over the adjacent Atlantic Ocean region (Fig. 4e, f). This is most 
(a)
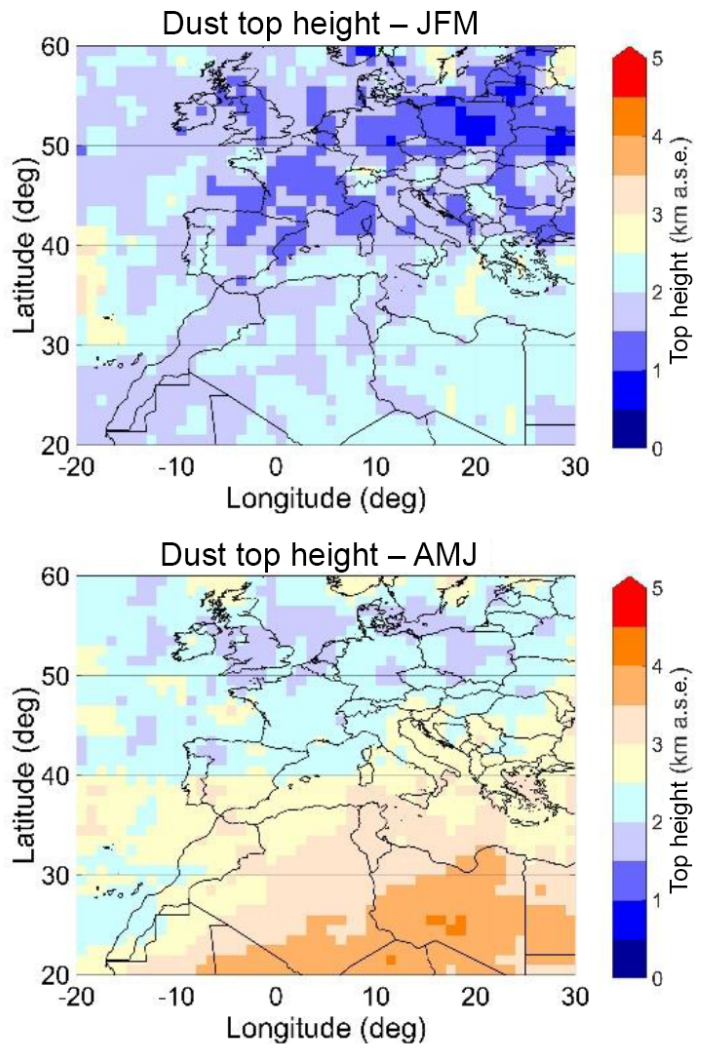

(c)

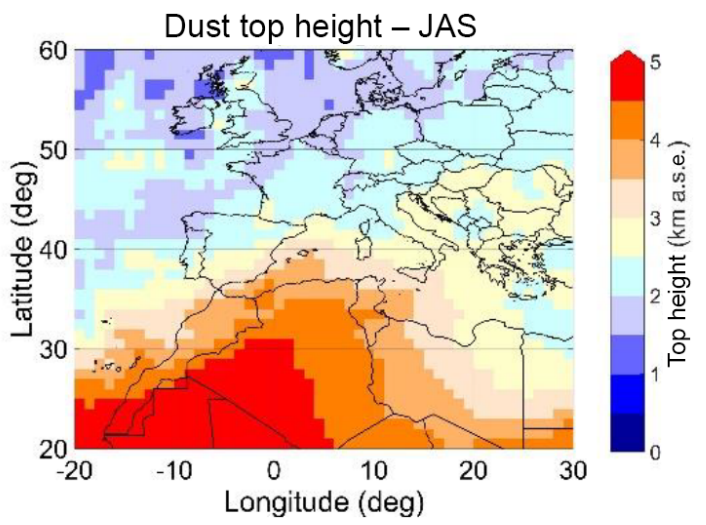

(e)

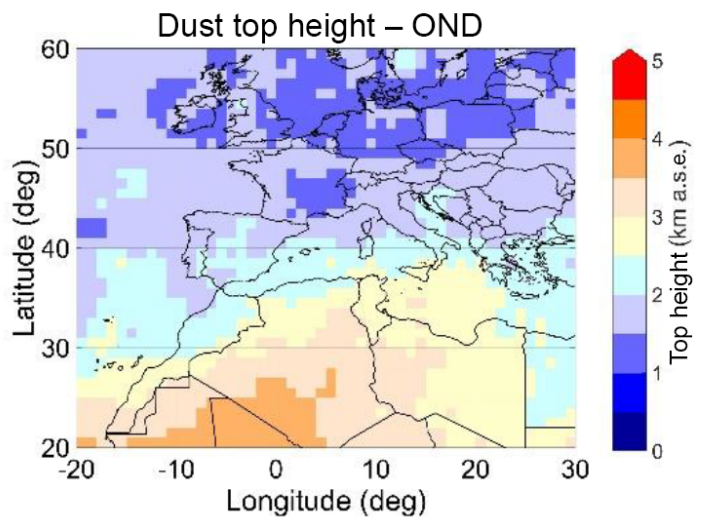

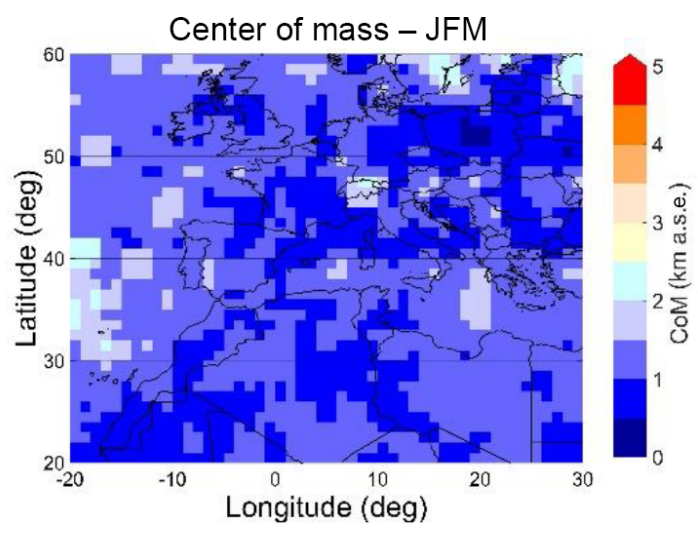

(b)

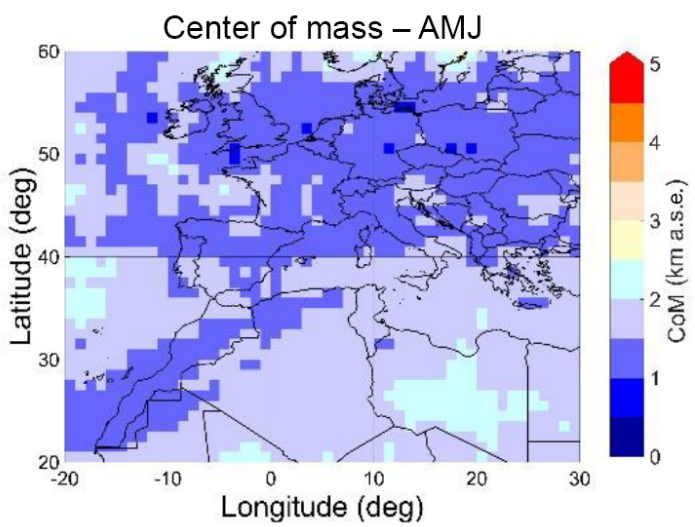

(d)

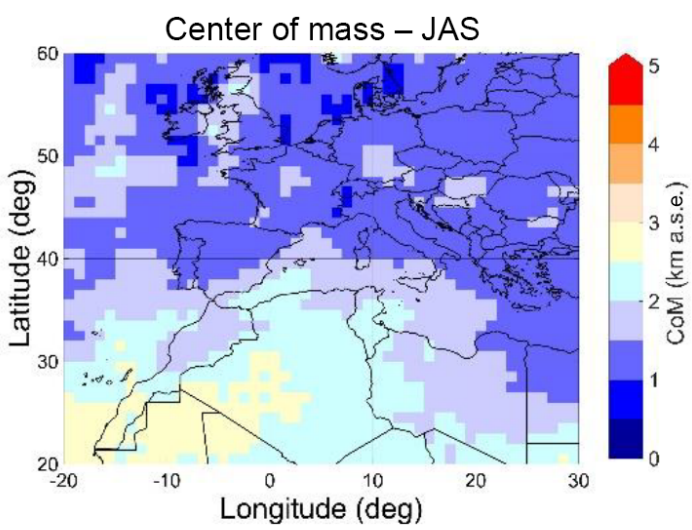

(f)

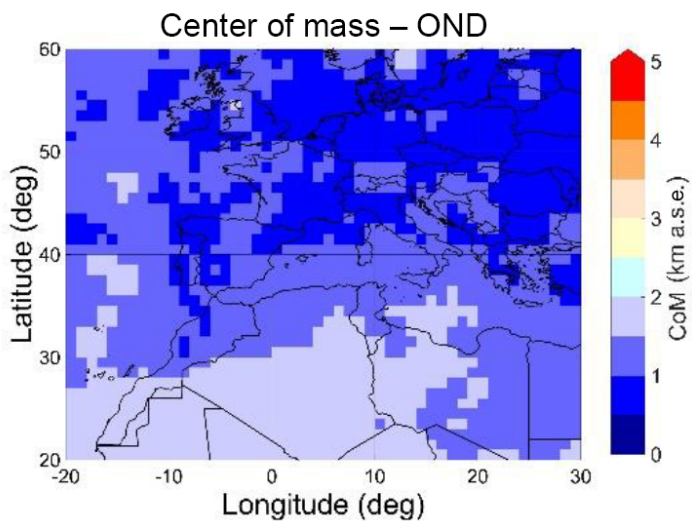

Figure 4. Geographical distribution of the dust top height (a-d) and the center of mass (e-h) in kma.s.e. measured with CALIPSO dust product for the 3-month averages: January-March (a, e), April-June (b, f), July-September (c, g), and October-November $(\mathbf{d}, \mathbf{h})$, and the domain between $20^{\circ} \mathrm{W}-30^{\circ} \mathrm{E}$ and $20-60^{\circ} \mathrm{N}$ for the period $2007-2015$. 
likely attributed to the intrusion of the lower tropospheric Atlantic monsoon, south of the ITCZ, and the development of mesoscale convective systems that favor the elevation of dust at this area (Bou Karam et al., 2008). The dust height decreases towards the eastern part of the study region. In the interim, the dominance of the strong Saharan high enables the mobilization of dust from the western part of the Sahara towards the western Mediterranean and Europe. This pattern leads to elevated dust at $3.0 \pm 1.7 \mathrm{~km}$ a.s.e. and CoM at $1.6 \pm 1.1 \mathrm{~km}$ a.s.e. over southern European countries and the Balkans. During OND the horizontal pattern is similar to JJA, however, with much lower heights (Fig. 4g, h).

In general, our results are in agreement with lidar-based studies which have been performed in several European sites. Papayannis et al. (2008) performed an exhaustive analysis on Saharan dust particles over Europe using EARLINET lidar profiles. They found that the dust layer center of mass extends from 3.0 to $3.8 \mathrm{~km}$ and the thickness ranges from 0.7 to $3.4 \mathrm{~km}$. Moreover, Balis (2012) calculated the mean base and top of dust layers in the eastern Mediterranean, Thessaloniki, to be around $2.5 \pm 0.9 \mathrm{~km}$ and $4.2 \pm 1.5 \mathrm{~km}$, respectively. More recently, Mona et al. (2014) analyzed a long dataset of Saharan dust intrusions over Potenza, Italy, and found a mean layer center of mass of $3.5 \pm 1.5 \mathrm{~km}$.

\subsection{Climatological dust cross sections}

To further illustrate the vertical dynamics of dust reaching Europe, the area of study between $20^{\circ} \mathrm{W}$ and $30^{\circ} \mathrm{E}$ is separated into five longitudinal zones of $10^{\circ}$, covering latitudes from 20 to $60^{\circ} \mathrm{N}$, and the results are presented as latitudeheight cross-section plots in Fig. 5, with the respective statistics in Table 3. The vertical structure of the averaged Climatological Dust Extinction coefficient (Clim-DE) for each of these five longitudinal zones reveals several dust layers and strong seasonal variations. The two dashed lines drawn in the cross-section plots show the number of dust observations averaged for the extinction retrievals. The extinction values below the higher dashed line correspond to $>18$ dust observations (two dust overpasses per season and year), whereas below the lower dashed line they correspond to $>54$ (two dust overpasses per month and year). The median surface elevation is depicted with black color (and is labeled as $\mathrm{NaN}$ ) in the plots.

Figure 5 shows that dust is always ubiquitous at heights close to the surface throughout the year. The lower layers are representative of near-source dust activity and boundary layer processes. The spring and summer peaks indicate the increased activity of Saharan dust sources (Moulin et al., 1998; Schepanski et al., 2007). More specifically, for the area between 10 and $20^{\circ} \mathrm{W}$ over the Atlantic, extending from Africa to the west of the Iberian Peninsula and Ireland (Fig. 5a-d), the presence of elevated dust plumes is evident mainly during summer and for latitudes up to $30^{\circ} \mathrm{N}$. During JFM the plume is located below $2 \mathrm{~km}$ height above sea level (a.s.l.), while from spring to autumn the plume reaches a height of $5 \mathrm{~km}$ a.s.l. and yields high values of extinction coefficient $\left(\sim 75 \mathrm{Mm}^{-1}\right)$ over Africa. Over the area from 0 to $10^{\circ}$ $\mathrm{W}$, extending from western Algeria, Morocco, the Iberian Peninsula and the British Isles, we found Clim-DE values inside the Africa mixing layer greater than $60 \mathrm{Mm}^{-1}$ for all seasons. Maximum values of extinction are observed during summer months when dust is elevated up to $6 \mathrm{~km}$ with ClimDE values around $120 \pm 140 \mathrm{Mm}^{-1}$ above N. Africa and mean values exceeding $200 \mathrm{Mm}^{-1}$ above the Algerian Desert (Fig. 5g). These findings are in good agreement with more than 2 years of AERONET observations in the Tamanrasset site, a strategic site for dust research located in the heart of the Sahara (Guirado et al., 2014). A steep decrease in extinction values is observed along the African coastline, with values of $20 \mathrm{Mm}^{-1}$ above the southern part of the Iberian Peninsula $\left(38-42^{\circ} \mathrm{N}\right)$ where dust is trapped by the Pyrenees. The distinct decrease of extinction values across the African coastline is an indication that dust is always present inside the rather deep Saharan boundary layer while it is only occasionally transferred towards the Mediterranean when atmospheric dynamics favor this kind of flow. At higher latitudes, the CALIPSO dust extinction is drastically reduced but still observed at $1-2 \mathrm{~km}$ a.s.l., with mean Clim-DE values of $5 \mathrm{Mm}^{-1}$. As discussed in detail in Sect. 2.4, the uncertainty of the dust extinction values close to the surface and at high latitudes is $<54 \%$, with the higher uncertainty in this region mainly originating from the selection of the $\delta_{\text {nd }}$ value during the dust separation step. Moreover, the standard deviation, coming from the natural variability of the dust events, is an order of magnitude higher than the mean values (Table 3). Moving eastwards $\left(0-10^{\circ} \mathrm{E}\right)$, elevated dust is trapped topographically by the Alps $\left(47-52^{\circ} \mathrm{N}\right)$, with values $>10 \mathrm{Mm}^{-1}$. As the dust-laden air-masses approach the mountains, they decelerate and their dust concentrations increase (Israelevich et al., 2012). Maximum values of extinction $\left(>50 \mathrm{Mm}^{-1}\right)$ are observed over northern Africa during summer (Fig. 5k). Close to the Algerian sources, south of the Atlas Mountains $\left(\sim 30^{\circ} \mathrm{N}\right)$, the extinction coefficient is greater than $200 \mathrm{Mm}^{-1}$ close to the surface (Fig. $4 \mathrm{k}$ ). The area south of the Atlas Mountains (Fig. 5e, f, g, h) is characterized by haboob activity (Knippertz et al., 2009; Solomos et al., 2012). These systems are generated from convective outflows and contribute to the interannual burden of dust at this area. As dust extends to higher latitudes (30$\left.40^{\circ} \mathrm{N}\right)$ Clim-DE decreases $\left(<75 \mathrm{Mm}^{-1}\right)$. Over the area between 10 and $20^{\circ} \mathrm{E}$ (Fig. 5m-p), similar patterns are observed. This region includes the dust sources of Libya and the central Sahara, the central Mediterranean, the eastern Alps and part of northern Europe. It is evident from this figure that dust extinction over the central Mediterranean $\left(35-45^{\circ} \mathrm{N}\right)$ is around $25 \mathrm{Mm}^{-1}$ throughout the year. As in the previous western zonal section, the same pattern over the Alps is encountered. Moving further eastwards, maximum values of Clim-DE are found during spring. At the most eastern part 
Table 3. Regional statistics on the dust extinction coefficient for altitudes between 0 and $2 \mathrm{~km}, 2$ and $4 \mathrm{~km}$ and 4 and $6 \mathrm{~km}$ (a.s.1.).

\begin{tabular}{|c|c|c|c|c|}
\hline & $0-2 \mathrm{~km}$ & $2-4 \mathrm{~km}$ & $4-6 \mathrm{~km}$ & \\
\hline & Clim-DE / Cond-DE / SD & Clim-DE / Cond-DE / SD & Clim-DE / Cond-DE / SD & Domain \\
\hline \multicolumn{5}{|c|}{ NE Africa } \\
\hline JFM & $42 / 50 / 74 \mathrm{Mm}^{-1}$ & $7 / 43 / 20 \mathrm{Mm}^{-1}$ & $0 / 25 / 5 \mathrm{Mm}^{-1}$ & \\
\hline AMJ & $66 / 66 / 88$ & $44 / 53 / 48$ & $18 / 48 / 26$ & {$\left[10^{\circ} \mathrm{E}, 30^{\circ} \mathrm{E}\right]$} \\
\hline JAS & $42 / 42 / 64$ & $30 / 40 / 37$ & $13 / 43 / 22$ & {$\left[20^{\circ} \mathrm{N}, 30^{\circ} \mathrm{N}\right]$} \\
\hline OND & $34 / 34 / 51$ & $17 / 32 / 24$ & $3 / 27 / 9$ & \\
\hline \multicolumn{5}{|c|}{ NW Africa } \\
\hline JFM & $46 / 60 / 80 \mathrm{Mm}^{-1}$ & $6 / 45 / 18 \mathrm{Mm}^{-1}$ & $0 / 29 / 5 \mathrm{Mm}^{-1}$ & \\
\hline AMJ & $73 / 73 / 90$ & $41 / 59 / 49$ & $13 / 51 / 25$ & {$\left[10^{\circ} \mathrm{W}, 10^{\circ} \mathrm{E}\right]$} \\
\hline JAS & $113 / 113 / 131$ & $83 / 83 / 71$ & $43 / 50 / 40$ & {$\left[20^{\circ} \mathrm{N}, 35^{\circ} \mathrm{N}\right]$} \\
\hline OND & $59 / 59 / 86$ & $35 / 48 / 43$ & $10 / 36 / 19$ & \\
\hline \multicolumn{5}{|c|}{ C-E Med. } \\
\hline JFM & $22 / 44 / 55 \mathrm{Mm}^{-1}$ & $4 / 48 / 16 \mathrm{Mm}^{-1}$ & $0 / 31 / 5 \mathrm{Mm}^{-1}$ & \\
\hline AMJ & $27 / 35 / 54$ & $17 / 52 / 34$ & $5 / 42 / 15$ & {$\left[10^{\circ} \mathrm{E}, 30^{\circ} \mathrm{E}\right]$} \\
\hline JAS & $18 / 18 / 28$ & $13 / 33 / 22$ & $4 / 37 / 12$ & {$\left[30^{\circ} \mathrm{N}, 45^{\circ} \mathrm{N}\right]$} \\
\hline OND & $19 / 23 / 32$ & $10 / 35 / 19$ & $2 / 27 / 7$ & \\
\hline \multicolumn{5}{|c|}{ C-W Med. } \\
\hline JFM & $5 / 24 / 33 \mathrm{Mm}^{-1}$ & $1 / 32 / 7 \mathrm{Mm}^{-1}$ & $0 / 21 / 2 \mathrm{Mm}^{-1}$ & \\
\hline AMJ & $10 / 23 / 38$ & $6 / 35 / 19$ & $1 / 31 / 8$ & {$\left[10^{\circ} \mathrm{W}, 10^{\circ} \mathrm{E}\right]$} \\
\hline JAS & $16 / 22 / 40$ & $13 / 33 / 23$ & $5 / 38 / 14$ & {$\left[35^{\circ} \mathrm{N}, 45^{\circ} \mathrm{N}\right]$} \\
\hline OND & $10 / 22 / 33$ & $4 / 29 / 14$ & $0 / 29 / 4$ & \\
\hline \multicolumn{5}{|c|}{ NE Europe } \\
\hline JFM & $4 / 37 / 41 \mathrm{Mm}^{-1}$ & $0 / 29 / 5 \mathrm{Mm}^{-1}$ & $0 / 15 / 1 \mathrm{Mm}^{-1}$ & \\
\hline AMJ & $8 / 17 / 27$ & $2 / 21 / 17$ & $0 / 14 / 2$ & {$\left[10^{\circ} \mathrm{E}, 30^{\circ} \mathrm{E}\right]$} \\
\hline JAS & $7 / 14 / 21$ & $2 / 16 / 9$ & $0 / 16 / 2$ & {$\left[45^{\circ} \mathrm{N}, 60^{\circ} \mathrm{N}\right]$} \\
\hline OND & $4 / 16 / 19$ & $1 / 21 / 6$ & $0 / 14 / 1$ & \\
\hline \multicolumn{5}{|c|}{ NW Europe } \\
\hline JFM & $1 / 16 / 16 \mathrm{Mm}^{-1}$ & $0 / 16 / 2 \mathrm{Mm}^{-1}$ & $0 / 15 / 1 \mathrm{Mm}^{-1}$ & \\
\hline AMJ & $4 / 16 / 16$ & $1 / 21 / 11$ & $0 / 14 / 2$ & {$\left[10^{\circ} \mathrm{W}, 10^{\circ} \mathrm{E}\right]$} \\
\hline JAS & $3 / 15 / 15$ & $1 / 22 / 7$ & $0 / 18 / 2$ & {$\left[45^{\circ} \mathrm{N}, 60^{\circ} \mathrm{N}\right]$} \\
\hline OND & $2 / 16 / 15$ & $0 / 23 / 4$ & $0 / 13 / 0$ & \\
\hline
\end{tabular}

of the study area $\left(20-30^{\circ} \mathrm{E}\right.$; Fig. $\left.5 \mathrm{q}-\mathrm{t}\right)$, dust is trapped by the Carpathian Mountains $\left(45-49^{\circ} \mathrm{N}\right)$ especially during winter, highlighting once more the role of topography. Significant dust presence is evident all over the zonal section (until $60^{\circ} \mathrm{N}$ ) and is mostly attributable to elevated dust traveling along with the westerlies from western and central parts of Europe towards the east. Above the Balkans and during JFM, values of $29 \pm 65 \mathrm{Mm}^{-1}$ are observed in the first $1.5 \mathrm{~km}$ and $10 \pm 30 \mathrm{Mm}^{-1}$ between 2.5 and $3.5 \mathrm{~km}$. In AMJ and JAS, respectively, mean values of $\sim 16 \pm 40 \mathrm{Mm}^{-1}$ and $\sim 9 \pm 20 \mathrm{Mm}^{-1}$ are observed at altitudes between 1.5 and $5 \mathrm{~km}$. Over Africa during winter and spring, the values of Clim-DE are higher $\left(>45 \mathrm{Mm}^{-1}\right)$ compared to the ones observed during the other two seasons $\left(<45 \mathrm{Mm}^{-1}\right)$, reaching high altitudes (5-6 km a.s.l.) during spring and summer. In summary, the obtained cross sections for the five longitudinal zones indicate that higher extinction coefficient values are observed near the source and at low altitudes, where dust particles are efficiently deposited.

The above results are representative of the spatial distribution of dust load as this is approximated by the aerosol extinction coefficient. In order to provide the dust load in units that are more relevant for modeling studies, we estimate here the dust mass concentration. The mass concentration can be obtained from the optical properties of dust with an uncertainty of 20-30\% (Ansmann et al., 2012; Mamouri and Ansmann, 2014). For example, the Clim-DE values correspond to dust mass concentrations $>75 \mu \mathrm{g} \mathrm{m}^{-3}$ above Africa 
Domain

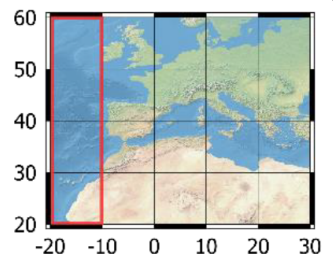

(a)

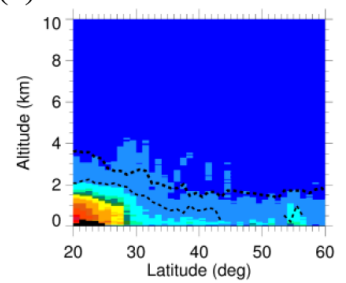

(e)

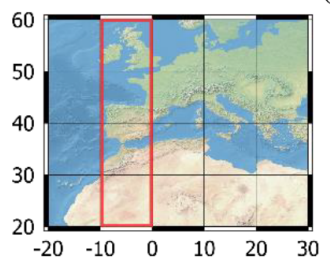

(i)

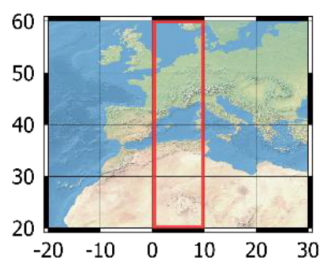

(m)
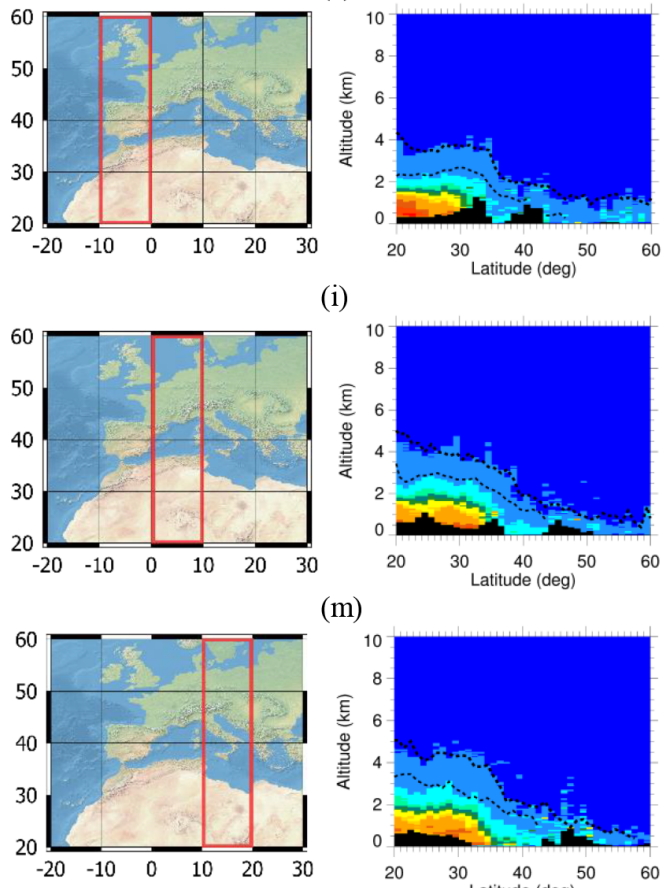

(1)

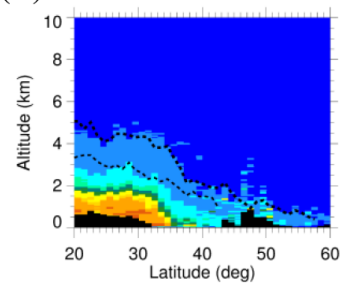

(q)

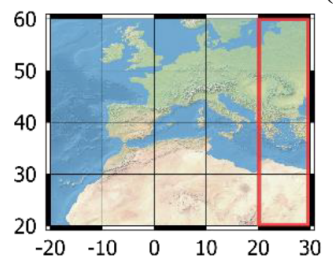

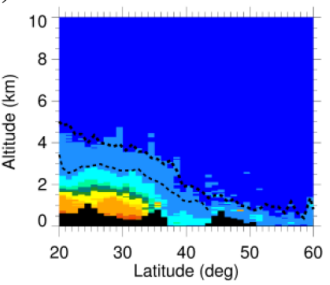

Jan-Feb-Mar

(b)

(f)

(j)

(n)

(r)

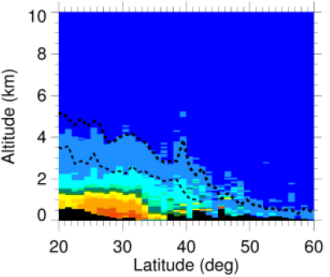

$$
\text { Apr-May-Jun }
$$
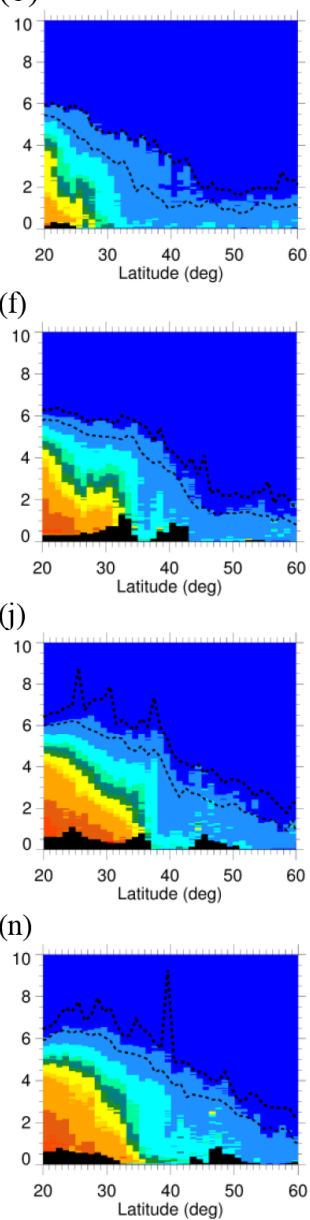

(c)

Jul-Aug-Sept

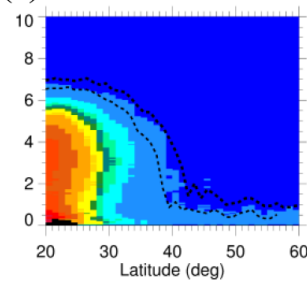

(g)

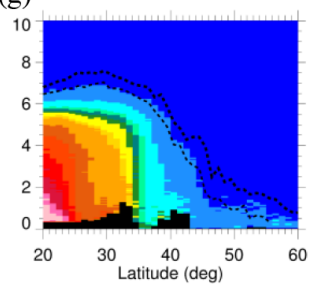

(k)

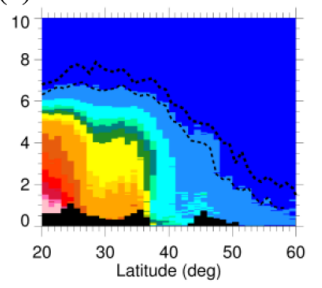

(o)
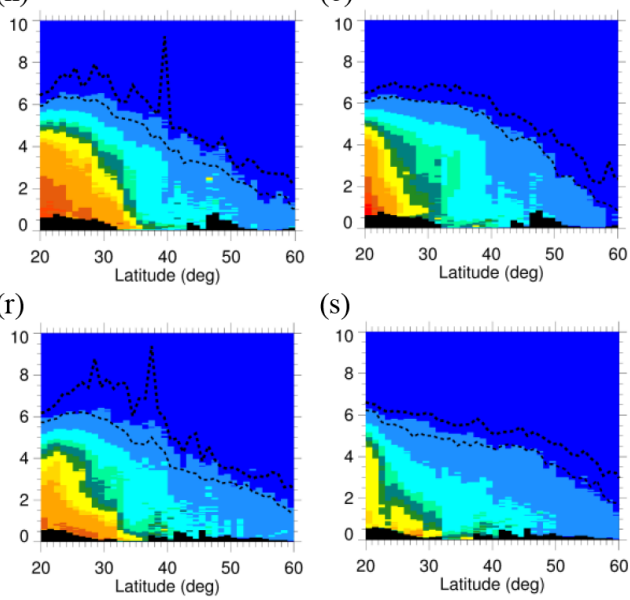

(s)

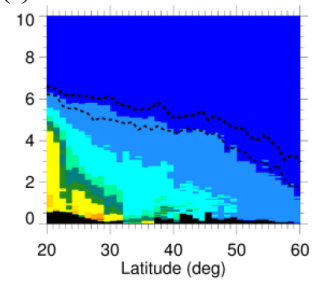

Oct-Nov-Dec

(d)

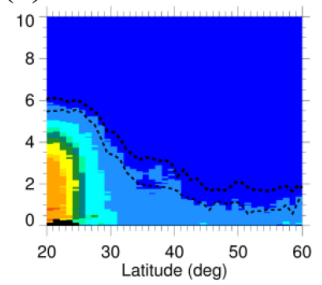

(h)

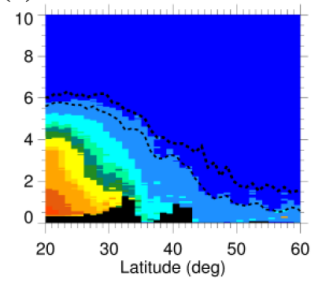

(1)

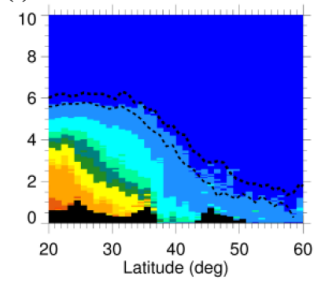

(p)

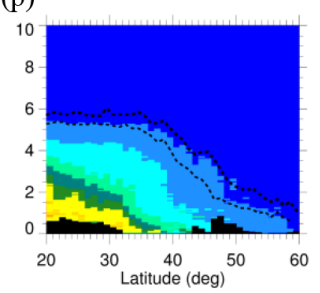

(t)

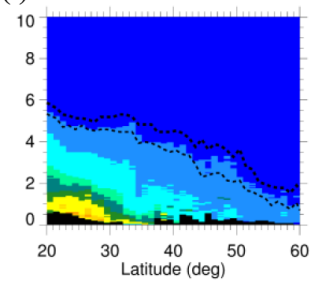

Dust extinction coefficient $\left(\mathrm{Mm}^{-1}\right)$

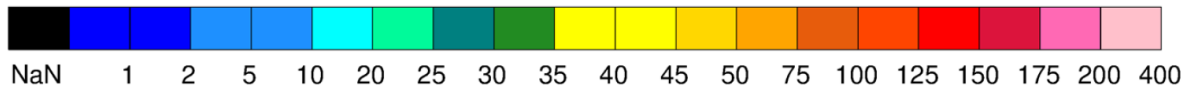

Figure 5. Geographical zonal distribution of the climatological dust extinction coefficient values $\left(\mathrm{Mm}^{-1}\right)$ measured by the CALIPSO dust product for the regions 10 to $20^{\circ} \mathrm{W}(\mathbf{a}-\mathbf{d}), 0$ to $10^{\circ} \mathrm{W}(\mathbf{e}-\mathbf{h}), 0$ to $10^{\circ} \mathrm{E}(\mathbf{i}-\mathbf{l}), 10$ to $20^{\circ} \mathrm{E}(\mathbf{m}-\mathbf{p})$ and 20 to $30^{\circ} \mathrm{E}$ (q-t) for the latitudinal regions from 10 to $60^{\circ} \mathrm{N}$ as illustrated by domain maps for the 3-month averages: January-March (a, e, i, m, q), April-June (b, f, j, n, r), July-September (c, $\mathbf{g}, \mathbf{k}, \mathbf{o}, \mathbf{s})$ and October-November $(\mathbf{d}, \mathbf{h}, \mathbf{l}, \mathbf{p}, \mathbf{t})$. The median surface elevation is depicted with black color.

throughout the year and $>125 \mu \mathrm{g} \mathrm{m}^{-3}$ above West Africa during JAS. In southern Europe and the Mediterranean, the corresponding values are $>17 \mu \mathrm{g} \mathrm{m}^{-3}$ in the first $2 \mathrm{~km}$ a.s.l. and $\sim 50 \mu \mathrm{g} \mathrm{m}^{-3}$ close to the surface. For latitudes greater than $45^{\circ} \mathrm{N}$, values of $\sim 8 \mu \mathrm{g} \mathrm{m}^{-3}$ are the most common.
The decreasing intensity with height and latitude of ClimDE is representative of the average dust distribution over the area. However, this behavior is not representative of the distribution during dust episodes over Europe. This is because the extinction coefficient values presented in Fig. 5 for the Clim-DE product are produced by averaging both par- 
tially and fully dominated dust cases. Conversely, the ConDE product presented in the next section describes the spatial patterns and the intensity of the dust plumes during the dust episodes only.

\subsection{Conditional dust cross sections}

The two dashed lines in Fig. 6 correspond to $>18$ dust observations (two dust overpasses per season and year) and $>54$ dust observations (two dust overpasses per month and year) for the lower and higher dashed line, respectively. Con$\mathrm{DE}$ values derived from less than 4 dust observations (dO) in each cell are masked with grey color (and are labeled as $<4 \mathrm{dO}$ ) in the plots. The median surface elevation is depicted with black color (same as in Fig. 5). Con-DE values are significantly different from the Clim-DE, as seen in Fig. 5. Although Con-DE has similar values to Clim-DE near the sources, where dust is always present, above the Atlantic and the Mediterranean Con-DE is characterized by significantly higher values. This is expected, since the two products differ mostly over areas which are not dominated by dust.

In the vertical cross-section plots of Fig. 6 the patterns of Con-DE show two distinct dust features: over the longitudinal zone from 20 to $30^{\circ} \mathrm{E}$ during summer (Fig. 6o) a distinctive feature is seen above North Africa extending from the surface to $\sim 5 \mathrm{~km}$ a.s.l. and a second feature is seen above the Mediterranean between 3 and $6 \mathrm{~km}$ a.s.l. The two distinct layers are also identified in other regions and in other seasons (e.g., Fig. 6a, 1, p, s, t). These populations are linked to two different processes: the near-surface dust at the southern parts of the study region is connected to fresh emissions from the dust sources, while the elevated plumes that extend north until $40^{\circ} \mathrm{N}$ are due to the advection of dust, associated to the seasonality of the long-range transport paths (Lelieveld et al., 2002; Israelevich et al., 2012; Huneeus et al., 2016). This separation is enhanced as one moves from the west to the east sectors. At the western part of the domain $\left(10-20^{\circ} \mathrm{W}\right)$ the near-surface and elevated dust probably originates from the same sources. Similar double layer patterns are found in all seasons and over all areas with various characteristics. For example, during JAS at the region extending from 0 to $10^{\circ} \mathrm{W}$ (Fig. 6g), the generation of dust from the source region is much more intense than the transportation of dust. For the same period, in the area 0 to $10^{\circ} \mathrm{E}$, the dust transportation above the Mediterranean between 3 and $6 \mathrm{~km}$ height, originating from the intense source regions, becomes much more important than the source emissions.

Moreover, the vertical cross-section plots in Fig. 6 show the rare but very intense elevated dust plumes during JFM (Fig. 6a, e, i, m). During that period, dust is advected between 1.5 and $4 \mathrm{~km}$ height a.s.l. with Con-DE values $>45 \mathrm{Mm}^{-1}$, equivalent to dust mass concentrations $>75 \mu \mathrm{g} \mathrm{m}^{-3}$. The intensity of the JFM dust episodes above the Balkans is also depicted (Fig. 6q): the Con-DE value is similar to other regions, but the dust plumes can be thicker, extending from the ground until $4 \mathrm{~km}$ a.s.l. The trapping of Saharan dust from the mountainous ridges of Europe (located between 40 and $50^{\circ} \mathrm{N}$, e.g., the Alps $45-48^{\circ} \mathrm{N}$ ) is also evident (e.g., Fig. 6i, $\mathrm{m})$. The deceleration of the transport air masses along the mountain ridges results in the accumulation of dust at the windward slopes. Dry deposition of dust at these areas also result in the formation of "brown snow" and albedo reduction, with profound climatological implications (e.g., Fujita, 2007; Shahgedanova et al., 2013). This phenomenon is more intense during the JFM period due to the advection of dust at lower heights.

During AMJ (Fig. 5b, f, j, n, r) and JAS (Fig. 5c, g, k, o, s) the elevated dust above the Mediterranean presents Con-DE values of $35-50 \mathrm{Mm}^{-1}\left(58-83 \mu \mathrm{g} \mathrm{m}^{-3}\right)$, in heights between 2 and $6 \mathrm{~km}$ and up to latitudes of $40^{\circ} \mathrm{N}$. The transport of dust during AMJ is mostly due to the eastward propagation of N. Africa-Mediterranean low pressure systems (Sharav cyclones). Dust is embedded in the cyclonic circulation and the penetration to latitudes higher than $40^{\circ} \mathrm{N}$ is limited. For latitudes 40 and $50^{\circ} \mathrm{N}$ during the warm seasons (AMJ and JAS), the Con-DE values inside the transported dust plumes are between 20 and $40 \mathrm{Mm}^{-1}\left(33-67 \mu \mathrm{g} \mathrm{m}^{-3}\right)$. Rare events, characterized by relatively higher Con-DE $\left(>35 \mathrm{Mm}^{-1}\right.$ and $>58 \mathrm{~g} \mathrm{~m} \mathrm{~m}^{-3}$ ) between 2 and $5 \mathrm{~km}$ a.s.l., are observed over the British Isles and Germany during OND (Fig. 6h, 1). These events, caused by the propagating low pressure systems over the east Atlantic, have been documented in detail from the EARLINET community reporting extinction coefficient values up to $200 \mathrm{Mm}^{-1}$ inside dust plumes (Ansmann et al., 2003; Müller et al., 2003). In the vertical cross-section plots of Fig. 6, it is evident that dust reaches the upper levels of the troposphere ( $>8 \mathrm{~km}$ a.s.l.), with Con-DE values of $\sim 10 \mathrm{Mm}^{-1}$ in all longitudinal zones and during all seasons. Dust occurrence is very low, close to zero for heights greater than $8 \mathrm{~km}$ a.s.l. during spring and summer and for heights greater than $6 \mathrm{~km}$ a.s.l. during autumn and winter. A quantitative representation of the Clim-DE and Con-DE products is provided in Table 3. In this, regional statistics of the two products, along with their standard deviation, are provided for three altitudinal ranges (0-2, 2-4 and 4-6 km a.s.l.).

\subsection{Interannual variability of dust}

In this section we present the CALIPSO-derived monthly mean DOD values, for the total column and for five individual layers $(0.18-0.5,0.5-1,1-2,2-4$ and $4-8 \mathrm{~km})$, in order to study their interannual variability during the 9-year period between 2007 and 2015. The selected layers are representative for both near-surface and long-range transported dust plumes. The data are aggregated on a $10^{\circ} \times 10^{\circ}$ cell over the study region. Using a first-order autoregressive linear regression model on the deseasonalized monthly DOD values (108 in total) as described in Zanis et al. (2006), temporal trends of DOD were calculated. We note that 9 years are considered a small period for a robust trend calculation 
Domain

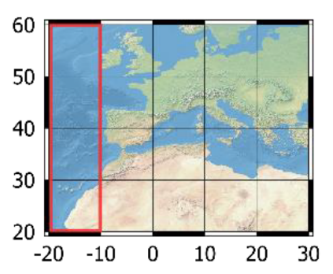

(e)

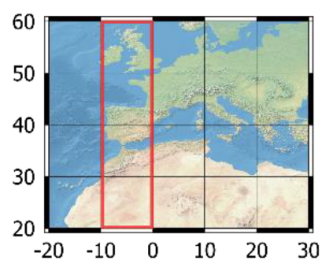

(i)

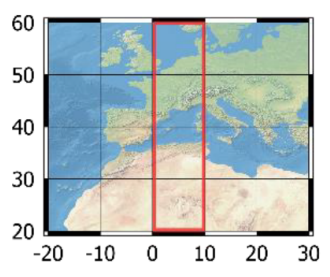

(m)
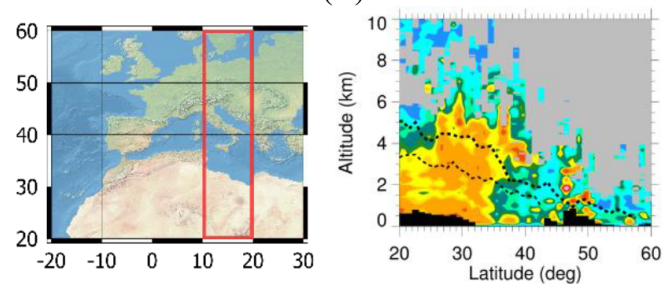

(q)

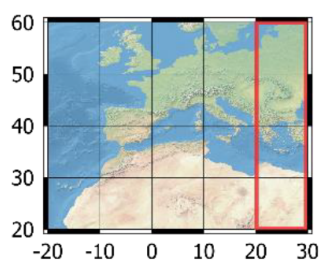

Jan-Feb-Mar

(a)
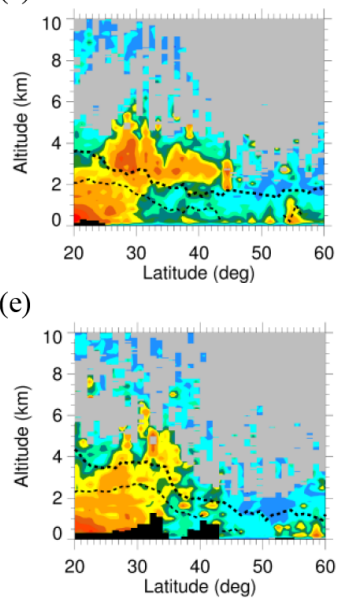

(i)

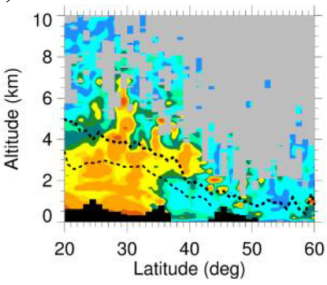

(n)

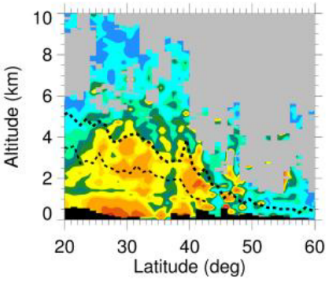

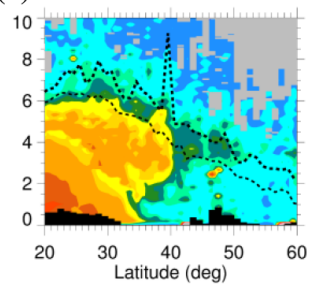

(r)

Apr-May-Jun

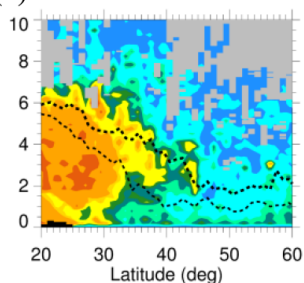

(f)

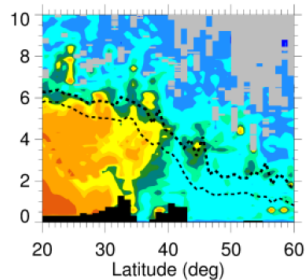

(j)

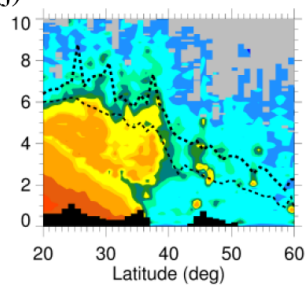

(n)

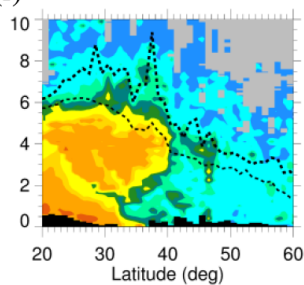

Jul-Aug-Sept

(c)

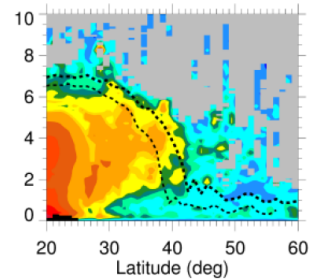

(g)

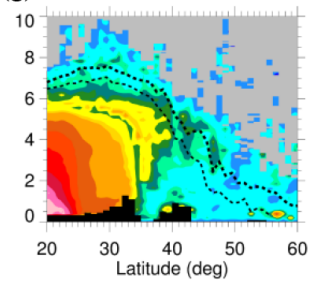

(k)

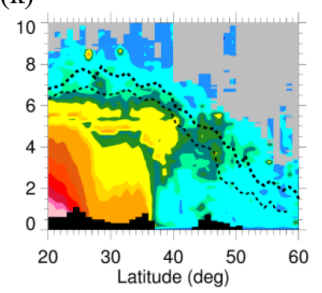

(o)

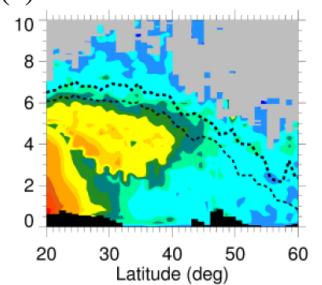

(s)

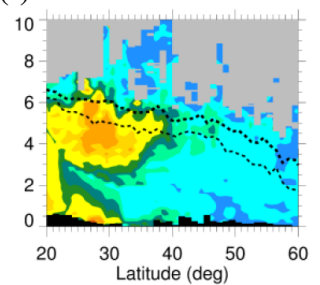

Oct-Nov-Dec

(d)

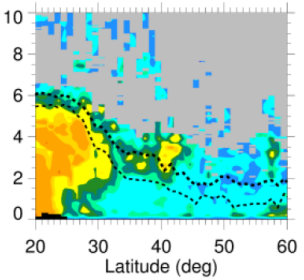

(h)

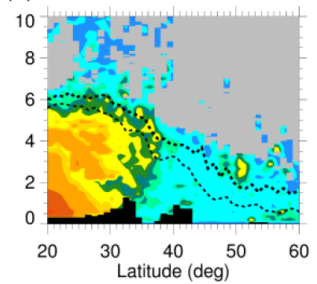

(l)

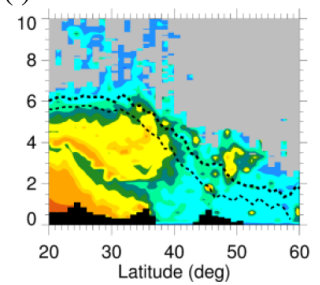

(p)

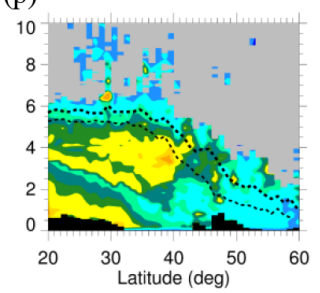

(t)

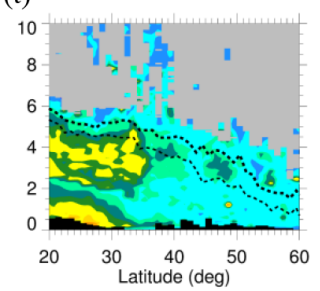

Conditional dust extinction coefficient $\left(\mathrm{Mm}^{-1}\right)$

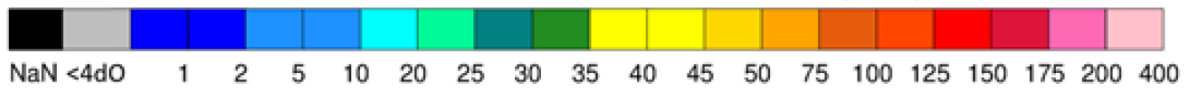

Figure 6. Geographical zonal distribution of the conditional dust extinction coefficient values $\left(\mathrm{Mm}^{-1}\right)$ measured by CALIPSO dust product for the regions 10 to $20^{\circ} \mathrm{W}(\mathbf{a}-\mathbf{d}), 0$ to $10^{\circ} \mathrm{W}(\mathbf{e}-\mathbf{h}), 0$ to $10^{\circ} \mathrm{E}(\mathbf{i}-\mathbf{l}), 10$ to $20^{\circ} \mathrm{E}(\mathbf{m}-\mathbf{p})$ and 20 to $30^{\circ} \mathrm{E}$ (q-t) for the latitudinal regions from $10^{\circ} \mathrm{N}$ to $60^{\circ} \mathrm{N}$ as illustrated by domain maps for the 3-month averages: January-March (a, e, i, m, q), April-June (b, f, j, n, r), July-September $(\mathbf{c}, \mathbf{g}, \mathbf{k}, \mathbf{o}, \mathbf{s})$ and October-November $(\mathbf{d}, \mathbf{h}, \mathbf{l}, \mathbf{p}, \mathbf{t})$. The median terrain elevation is depicted with black color.

and it would be interesting to extend this analysis with future measurements. Figure 7 shows the geographical distribution of deseasonalized trends $\left(\mathrm{yr}^{-1}\right)$ for the columnar DOD (a) and for the five individual layers (b-f). Hatched filled grid cells depict the statistical significance trends with $99 \%$ confidence. A decrease of $\sim 0.001 \mathrm{yr}^{-1}\left(\sim 4 \% \mathrm{yr}^{-1}\right)$ is evident for the southern European cells $\left(0-30^{\circ} \mathrm{E}, 40-\right.$ $50^{\circ} \mathrm{N}$ ) (with these values being $>95 \%$ statistically significant). Examination of the five vertical layers shows a similar decreasing pattern. The negative trends observed in the area (mainly above North Africa and the Mediterranean) show a constant decrease throughout the layers as well, although 
(a)
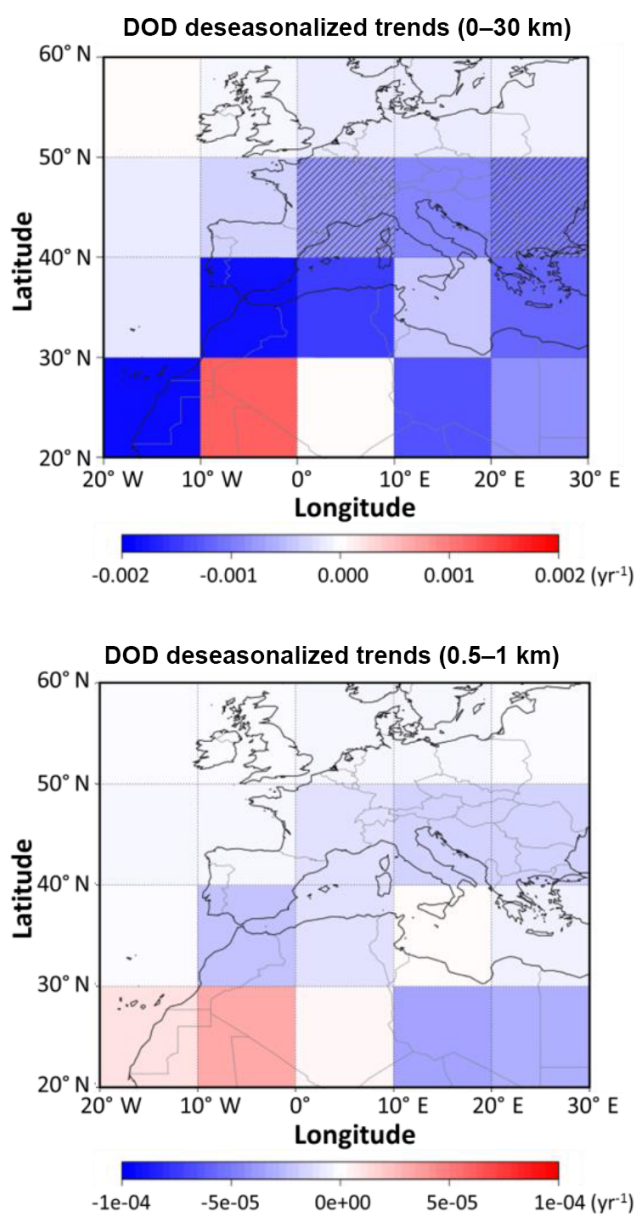

(c)

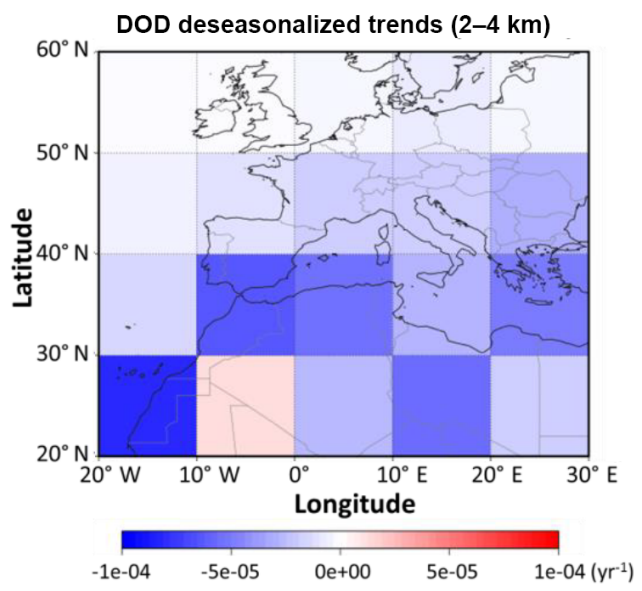

(b)
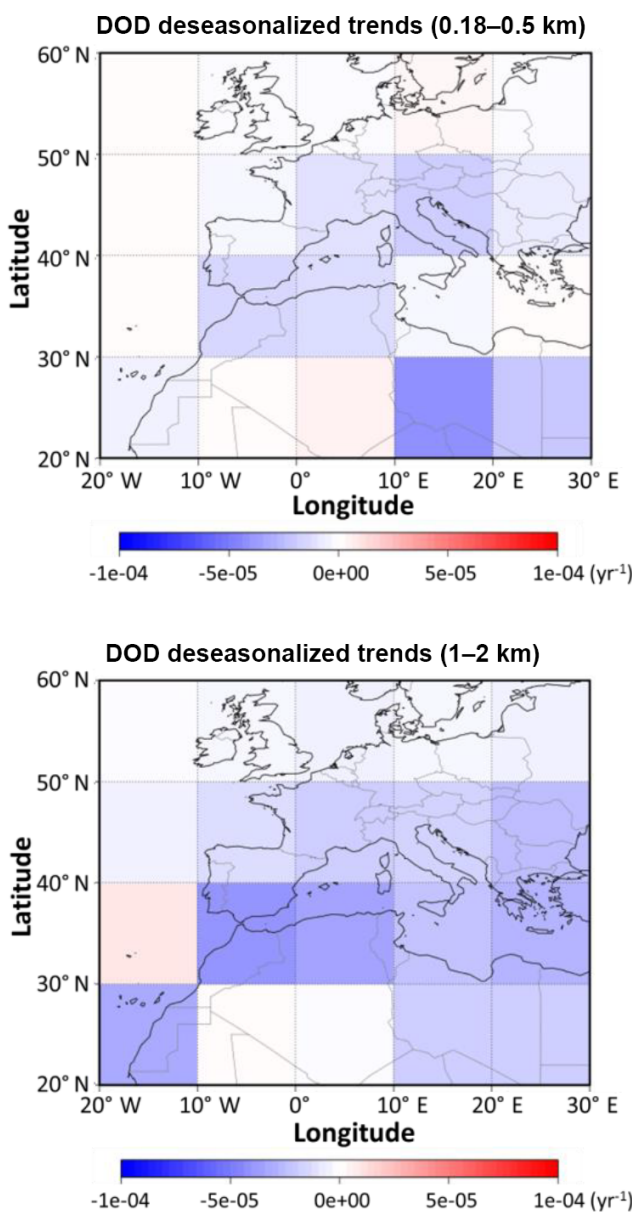

(d)

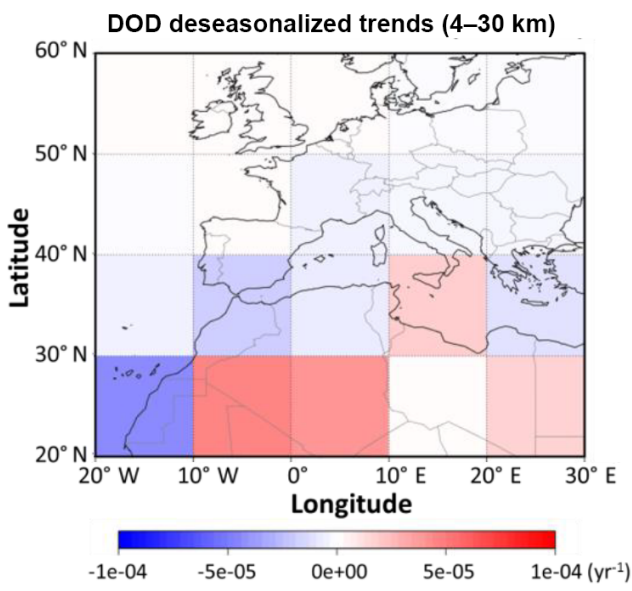

Figure 7. Geographical distribution of the deseasonalized trends $\left(\mathrm{yr}^{-1}\right)$ derived from monthly columnar DOD (a) and for five individual layers (b-f), for the period 2007-2015, aggregated over $10^{\circ} \times 10^{\circ}$ grid cells. Hatched filled grid cells depict the statistical significance trends with $99 \%$ confidence.

the trends are not statistically significant. The small negative DOD trends $\left(<0.002 \mathrm{yr}^{-1}\right.$ corresponding to $<5 \% \mathrm{yr}^{-1}$ ) are in good agreement with the global decrease of dust estimated from a 161-year time series of dust from 1851 to 2011 , created by projecting wind field patterns onto surface winds from a historical reanalysis in Evan et al. (2016). The agreement is also good with the global mean near-surface dust concentration decrease of $1.2 \% \mathrm{yr}^{-1}$ reported in Shao et al.'s (2013) paleoclimate research for the period 19842012, even though Europe and North America are excluded 

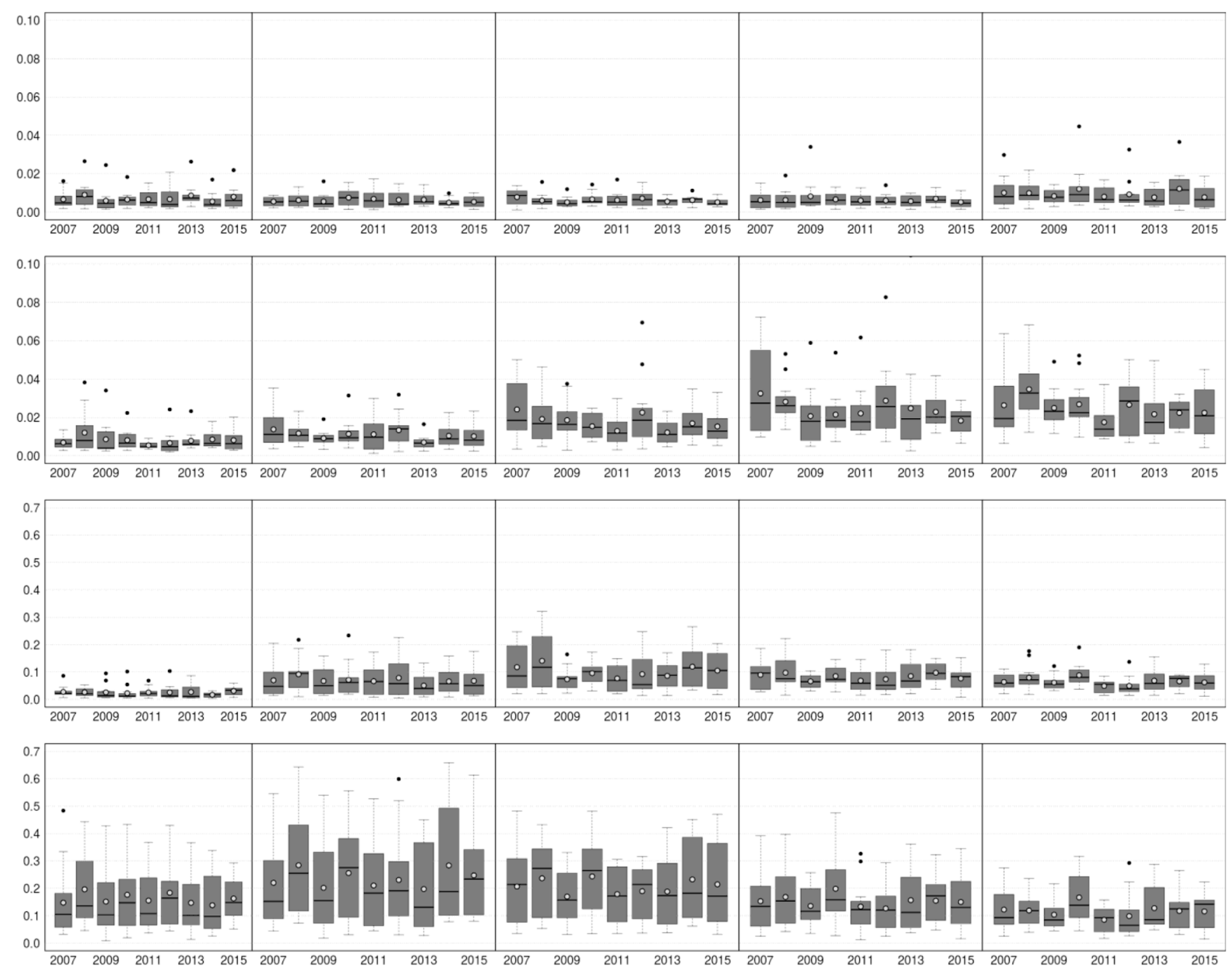

Figure 8. Interannual variability of the DODs for the $10^{\circ} \times 10^{\circ}$ grid cells depicted in Fig. 7, for the period $2007-2015$.

from their trend analysis. In comparison with studies relevant to the time period considered in this work, the DOD decrease of $0.001 \mathrm{yr}^{-1}$ over the northern coast of Africa is in agreement with Floutsi et al. (2016), who based their analysis on 12 years of MODIS-Aqua observations (20022014), reporting an average decrease of $0.003 \mathrm{yr}^{-1}$ for the coarse mode fraction of the AOD over the broader Mediterranean Sea. Furthermore, over the same domain the decreasing trend of DOD agrees well with the decrease of Saharan desert dust episodes as reported by Gkikas et al. (2013). Regarding the AERONET stations over the domain of northern Africa and Europe, Yoon et al. (2012) reported trends of AOD at $440 \mathrm{~nm}$ along with the corresponding ångström Exponents (440 and $870 \mathrm{~nm}$ ). The documented negative trends over the AERONET stations of Avignon (France), Dakar (Senegal) and Ispra (Italy) are in agreement with the negative DOD reported here, although with discrepancies in the magnitude, while trend disagreements are observed over the
AERONET station of Banizoumbou (Niger). The decreasing trends of DOD observed over the domain northern of Africa and Europe coincide with the documented downward AOD trends reported based on several satellite observations of MODIS-Aqua, MODIS-Terra, MISR and SeaWiFS (Pozzer et al., 2015; de Meij et al., 2012; Hsu et al., 2012; Georgoulias et al., 2016b). Particularly in the most recent study of Georgoulias et al. (2016b), using MODISTerra and MODIS-Aqua observations, negative statistically significant trends are reported over Algeria, Egypt and the Mediterranean and positive trends over the Middle East. Overall, for the Mediterranean they reported an AOD trend of $-0.0008 \mathrm{yr}^{-1}$ for the MODIS-Terra observations (20002015) and $-0.0020 \mathrm{yr}^{-1}$ for the MODIS-Aqua observations (2002-2015), with the trends being statistically significant at the $95 \%$ confidence level in both cases. A possible increase is only found for the western Sahara areas $\left(10-0^{\circ} \mathrm{W}\right.$, $\left.20-30^{\circ} \mathrm{N}\right)$. However, the results for this cell are not statisti- 
cally significant. Figure 8 shows the DOD interannual variability of the 20 individual areas, as it is calculated from the monthly mean DODs. It is evident from this figure that the DOD values in 2008 are relatively higher than the other years and in almost all the domains below $40^{\circ} \mathrm{N}$. Similarly, relatively high values are observed in some of these areas for the year 2010. Since these years are at the beginning of our study period, they have a significant contribution on the negative trends observed during the examined period.

\section{Summary and conclusions}

An optimized CALIPSO dust product was recently developed by Amiridis et al. (2013) using a regional correction for the Saharan dust lidar ratio derived from EARLINET measurements. The same product is used here to provide the three-dimensional dust distribution and its transport pathways across northern Africa and Europe from 2007 to 2015. The study of the mean state climatology shows strong seasonal shifts in dust source regions and transportation pathways. The seasonal cycle of the dust transport is well captured with the lowest values of DOD in winter and the highest values in spring and summer. During summer and autumn, dust aerosols are mostly confined to the source region, while during spring dust aerosols from the Sahara are extended uniformly over the northern Sahara and are transported over the Mediterranean and Europe. The dust extinction coefficient, $\mathrm{CoM}$ and $\mathrm{TH}$ parameters are used to quantitatively describe the 3-D evolution of dust and its seasonal variations. Over the source region of the Sahara Desert, dust CoM and TH are higher during spring and summer and lower during winter. Dust transport mechanisms are more efficient during summer when dust is often lifted up to $6 \mathrm{~km}$, coinciding with the deepest dust layer. Localized regions of increased extinction coefficient values over mountains (the Alps, the Pyrenees and the Carpathian Mountains) trace the aerosol transport routes that decelerate in front of the mountain ranges. Rare and intense events are observed above the Balkans during the winter period and above northwest Europe during autumn. The interannual analysis revealed that DOD trends during the study period are of the order of $0.001 \mathrm{yr}^{-1}$ for southern Europe, showing constant decrease throughout the different layers.

The dust climatology presented here is of paramount importance in understanding the three-dimensional production and transport of Saharan dust, providing valuable information for better estimations of the dust climatic impacts. The climatological and conditional products presented here describe both the dust contribution to the total aerosol load over our domain as well as the Saharan dust events recorded in the region, respectively. Future work includes (i) the optimization of CALIPSO dust retrievals based on measured dust LR from ground-based lidars and particle depolarization ratio over extended regions of deserts in the Middle East and China, to obtain a robust global climatology of dust; and (ii) the calculation of cloud condensation nuclei $(\mathrm{CCN})$ and ice nuclei (IN) concentrations from polarization lidar measurements as suggested by Mamouri and Ansmann (2016), to provide a quantification of the climatic effect of dust on cloud formation.

Data availability. The CALIPSO data were obtained from the online archive of the ICARE Data and Services center http:// www.icare.univ-lille1.fr/archive (CALIPSO Science Team, 2015; ICARE Data Center, 2016). MODIS data are publicly available on the NASA Giovanni system (https://giovanni.sci.gsfc. nasa.gov/giovanni/). MACC data are publicly available on http:// apps.ecmwf.int/datasets/data/macc-reanalysis/levtype=sfc/. The regional climate model ReGCM4 code is available at https://gforge. ictp.it/gf/project/regcm/frs/. RegCM4 simulation data used in this work are available upon request from Athanasios Tsikerdekis (tsike@geo.auth.gr). The LIVAS database is publicly available at http://lidar.space.noa.gr:8080/livas/. LIVAS EARLINET-optimized pure-dust products are available upon request from Eleni Marinou (elmarinou@noa.gr) and Vasilis Amiridis (vamoir@noa.gr).

Competing interests. The authors declare that they have no conflict of interest.

Acknowledgements. The authors acknowledge support through the following projects and research programs:

- ESA-ESTEC project LIVAS (contract no 4000104106/11/NL/FF/fk),

- BEYOND under grant agreement no. 316210 of the European Union Seventh Framework Programme (FP7-REGPOT-20122013-1),

- MarcoPolo under grant agreement no. 606953 from the European Union Seventh Framework Programme (FP7/2007-2013),

- ACTRIS under grant agreement no. 262254 of the European Union Seventh Framework Programme (FP7/2007-2013),

- ACTRIS-2 under grant agreement no. 654109 from the European Union's Horizon 2020 Research and Innovation Programme,

- ITaRS under grant agreement no. 289923 of the European Union Seventh Framework Programme (FP7/2007-2013),

- ECARS under grant agreement No 602014 from the European Union's Horizon 2020 Research and Innovation programme,

- EPAN II and PEP under the national action "Bilateral, multilateral and regional R\&T cooperations" (AEROVIS Sino-Greek project), and

- A. G. Leventis Foundation scholarship.

The authors acknowledge EARLINET for providing aerosol lidar profiles available under the World Data Center for Climate (WDCC; The EARLINET publishing group 2000-2010, 2014a, b, $\mathrm{c}, \mathrm{d}, \mathrm{e})$. We thank the AERONET PIs and their staff for establishing and maintaining the AERONET sites used in this investigation. CALIPSO data were obtained from the ICARE Data Center 
(http://www.icare.univ-lille1.fr/). CALIPSO data were provided by NASA. We thank the ICARE Data and Services Center for providing access to the data used in this study and their computational center. We thank Jason Tackett for his support during the algorithm development for the production of Level 3 CALIPSO products.

Edited by: M. Tesche

Reviewed by: four anonymous referees

\section{References}

Adams, A. M., Prospero, J. M., and Zhang, C.: CALIPSODerived Three-Dimensional Structure of Aerosol over the Atlantic Basin and Adjacent Continents, J. Climate, 25, 6862-6879, doi:10.1175/JCLI-D-11-00672.1, 2012.

Alpert, P., and Ganor, E.: Sahara mineral dust measurements from TOMS: Comparison to surface observations over the Middle East for the extreme dust storm, 14-17 March 1998, J. Geophys. Res., 106, 18275-18286, doi:10.1029/2000JD900366, 2001.

Amiridis, V., Balis, D. S., Giannakaki, E., Stohl, A., Kazadzis, S., Koukouli, M. E., and Zanis, P.: Optical characteristics of biomass burning aerosols over Southeastern Europe determined from UVRaman lidar measurements, Atmos. Chem. Phys., 9, 2431-2440, doi:10.5194/acp-9-2431-2009, 2009.

Amiridis, V., Wandinger, U., Marinou, E., Giannakaki, E., Tsekeri, A., Basart, S., Kazadzis, S., Gkikas, A., Taylor, M., Baldasano, J., and Ansmann, A.: Optimizing CALIPSO Saharan dust retrievals, Atmos. Chem. Phys., 13, 12089-12106, doi:10.5194/acp-1312089-2013, 2013.

Amiridis, V., Marinou, E., Tsekeri, A., Wandinger, U., Schwarz, A., Giannakaki, E., Mamouri, R., Kokkalis, P., Binietoglou, I., Solomos, S., Herekakis, T., Kazadzis, S., Gerasopoulos, E., Proestakis, E., Kottas, M., Balis, D., Papayannis, A., Kontoes, C., Kourtidis, K., Papagiannopoulos, N., Mona, L., Pappalardo, G., Le Rille, O., and Ansmann, A.: LIVAS: a 3-D multi-wavelength aerosol/cloud database based on CALIPSO and EARLINET, Atmos. Chem. Phys., 15, 7127-7153, doi:10.5194/acp-15-71272015, 2015.

Ansmann, A., Bösenberg, J., Chaikovsky, A., Comeron, A., Eckhardt, S., Eixmann, R., Freudenthaler, V., Ginoux, P., Komguem, L., Linne, H., Lopez Marquez, M. A., Matthias, V., Mattis, I., Mitev, V., Muller, D., Music, S., Nickovic, S., Pelon, J., Sauvage, L., Sobolewsky, P., Srivastava, M. K., Stohl, A., Torres, O., Vaughan, G., Wandinger, U., and Wiegner, M.: Long-range transport of Saharan dust to northern Europe: The 11-16 October 2001 outbreak observed with EARLINET, J. Geophys. Res., 108, 4783, doi:10.1029/2003JD003757, 2003.

Ansmann, A., Petzold, A., Kandler, K., Tegen, I., Wendisch, M., Muller, D., Weinzierl, B., Muller, T., and Heintzenberg, J.: Saharan Mineral Dust Experiments SAMUM-1 and SAMUM-2: what have we learned?, Tellus B, 63, 403-429, doi:10.1111/j.1600-0889.2011.00555.x., 2011.

Ansmann, A., Seifert, P., Tesche, M., and Wandinger, U.: Profiling of fine and coarse particle mass: case studies of Saharan dust and Eyjafjallajökull/Grimsvötn volcanic plumes, Atmos. Chem. Phys., 12, 9399-9415, doi:10.5194/acp-12-9399-2012, 2012.

Antoine, D. and Nobileau, D.: Recent increase of Saharan dust transport over the Mediterranean Sea, as revealed from ocean color satellite (SeaWiFS) observations, J. Geophys. Res., 111, D12214, doi:10.1029/2005JD006795, 2006.

Baars, H., Kanitz, T., Engelmann, R., Althausen, D., Heese, B., Komppula, M., Preißler, J., Tesche, M., Ansmann, A., Wandinger, U., Lim, J.-H., Ahn, J. Y., Stachlewska, I. S., Amiridis, V., Marinou, E., Seifert, P., Hofer, J., Skupin, A., Schneider, F., Bohlmann, S., Foth, A., Bley, S., Pfüller, A., Giannakaki, E., Lihavainen, H., Viisanen, Y., Hooda, R. K., Pereira, S. N., Bortoli, D., Wagner, F., Mattis, I., Janicka, L., Markowicz, K. M., Achtert, P., Artaxo, P., Pauliquevis, T., Souza, R. A. F., Sharma, V. P., van Zyl, P. G., Beukes, J. P., Sun, J., Rohwer, E. G., Deng, R., Mamouri, R.-E., and Zamorano, F.: An overview of the first decade of PollyNET: an emerging network of automated Raman-polarization lidars for continuous aerosol profiling, Atmos. Chem. Phys., 16, 5111-5137, doi:10.5194/acp-165111-2016, 2016.

Balis, D. S., Amiridis, V.,Nickovic, S., Papayannis, A., and Zerefos, C.: Optical properties of Saharan dust layers as detected by a Raman lidar at Thessaloniki, Greece, Geophys. Res. Lett., 31, L13104, doi:10.1029/2004GL019881, 2004.

Balis, D.: Geometrical characteristics of desert dust layers over Thessaloniki estimated with backscatter/Raman lidar and the BSC/DREAM model, Remote Sens. Lett., 3, 353-362, doi:10.1080/01431161.2011.597793, 2012.

Balkanski, Y., Schulz, M., Claquin, T., and Guibert, S.: Reevaluation of Mineral aerosol radiative forcings suggests a better agreement with satellite and AERONET data, Atmos. Chem. Phys., 7, 81-95, doi:10.5194/acp-7-81-2007, 2007.

Barnaba, F. and Gobbi, G. P.: Aerosol seasonal variability over the Mediterranean region and relative impact of maritime, continental and Saharan dust particles over the basin from MODIS data in the year 2001, Atmos. Chem. Phys., 4, 2367-2391, doi:10.5194/acp-4-2367-2004, 2004.

Binietoglou, I., Basart, S., Alados-Arboledas, L., Amiridis, V., Argyrouli, A., Baars, H., Baldasano, J. M., Balis, D., Belegante, L., Bravo-Aranda, J. A., Burlizzi, P., Carrasco, V., Chaikovsky, A., Comerón, A., D’Amico, G., Filioglou, M., Granados-Muñoz, M. J., Guerrero-Rascado, J. L., Ilic, L., Kokkalis, P., Maurizi, A., Mona, L., Monti, F., Muñoz-Porcar, C., Nicolae, D., Papayannis, A., Pappalardo, G., Pejanovic, G., Pereira, S. N., Perrone, M. R., Pietruczuk, A., Posyniak, M., Rocadenbosch, F., Rodríguez-Gómez, A., Sicard, M., Siomos, N., Szkop, A., Terradellas, E., Tsekeri, A., Vukovic, A., Wandinger, U., and Wagner, J.: A methodology for investigating dust model performance using synergistic EARLINET/AERONET dust concentration retrievals, Atmos. Meas. Tech., 8, 3577-3600, doi:10.5194/amt-83577-2015, 2015.

Bou Karam, D., Flamant, C., Knippertz, P., Reitebuch, O., Pelon, J., Chong, M., and Dabas, A.: Dust emissions over the Sahel associated with the West African monsoon intertropical discontinuity region: A representative case-study, Q. J. R. Meteor. Soc., 134, 621-634, doi:10.1002/qj.244, 2008.

Bovchaliuk, V., Goloub, P., Podvin, T., Veselovskii, I., Tanre, D., Chaikovsky, A., Dubovik, O., Mortier, A., Lopatin, A., Korenskiy, M., and Victori, S.: Comparison of aerosol properties retrieved using GARRLiC, LIRIC, and Raman algorithms applied to multi-wavelength lidar and sun/sky-photometer data, Atmos. Meas. Tech., 9, 3391-3405, doi:10.5194/amt-9-3391-2016, 2016. 
Burton, S. P., Ferrare, R. A., Vaughan, M. A., Omar, A. H., Rogers, R. R., Hostetler, C. A., and Hair, J. W.: Aerosol classification from airborne HSRL and comparisons with the CALIPSO vertical feature mask, Atmos. Meas. Tech., 6, 13971412, doi:10.5194/amt-6-1397-2013, 2013.

CALIPSO L2-V3: CALIPSO Quality Statements: Lidar Level 2 Cloud and Aerosol Profile Products Version Releases: 3.01, 3.02, available at: https://eosweb.larc.nasa.gov/sites/ default/files/project/calipso/quality_summaries/CALIOP L2ProfileProducts_3.01.pdf (last access: 1 March 2017), 2010.

CALIPSO L3-V3: CALIPSO: Data User's Guide Data Quality Statement - Lidar Level 3 Aerosol Profile Monthly Product Version 3.00, available at: http://www-calipso.larc.nasa.gov/resources/calipso_users_ guide/data_summaries/13/CALIOP_L3Products_3-00_v01.php (last access: 1 March 2017), 2015.

CALIPSO Science Team (2015), CALIPSO/CALIOP Level 2, Lidar Aerosol Profile Data, version 3.30, Hampton, VA, USA: NASA Atmospheric Science Data Center (ASDC), doi:10.5067/CALIOP/CALIPSO/CAL_LID_L2_05kmAProProv-V3-30_L2-003.30, 2015.

Cuevas, E., Camino, C., Benedetti, A., Basart, S., Terradellas, E., Baldasano, J. M., Morcrette, J. J., Marticorena, B., Goloub, P., Mortier, A., Berjón, A., Hernández, Y., Gil-Ojeda, M., and Schulz, M.: The MACC-II 2007-2008 reanalysis: atmospheric dust evaluation and characterization over northern Africa and the Middle East, Atmos. Chem. Phys., 15, 3991-4024, doi:10.5194/acp-15-3991-2015, 2015.

de Meij, A., Pozzer, A., Pringle, K. J., Tost, H., and Lelieveld, J.: EMAC model evaluation and analysis of atmospheric aerosol properties and distribution, Atmos. Res, 114-115, 38-69, doi:10.1016/j.atmosres.2012.05.014, 2012.

DeMott, P. J., Sassen, K., Poellot, M. R., Baumgardner, D., Rogers, D. C., Brooks, S. D., Prenni, A. J., and Kreidenweis, S. M.: African dust aerosols as atmospheric ice nuclei, Geophys. Res. Lett., 30, 1732, doi:10.1029/2003GL017410, 2003.

The EARLINET publishing group 2000-2010: Adam, M., AladosArboledas, L., Al-thausen, D., Amiridis, V., Amodeo, A., Ansmann, A., Apituley, A., Arshinov, Y., Balis, D., Belegante, L., Bobrovnikov, S., Boselli, A., Bravo-Aranda, J. A., Bösen-berg, J., Carstea, E., Chaikovsky, A., Comerón, A., D’Amico, G., Daou, D., Dreischuh, T., Engelmann, R., Finger, F., Freudenthaler, V., Garcia-Vizcaino, D., García, A. J. F., Geiß, A., Giannakaki, E., Giehl, H., Giunta, A., de Graaf, M., Grana-dosMuñoz, M. J., Grein, M., Grigorov, I., Groß, S., Gruening, C., Guerrero-Rascado, J. L., Haeffelin, M., Hayek, T., Iarlori, M., Kanitz, T., Kokkalis, P., Linné, H., Ma-donna, F., Mamouriat, R.-E., Matthias, V., Mattis, I., Menéndez, F. M., Mitev, V., Mona, L., Morille, Y., Muñoz, C., Müller, A., Müller, D., Navas-Guzmán, F., Nemuc, A., Nicolae, D., Pandolfi, M., Papayannis, A., Pappalardo, G., Pelon, J., Perrone, M. R., Pietruczuk, A., Pisani, G., Potma, C., Preißler, J., Pujadas, M., Putaud, J., Radu, C., Ravetta, F., Reigert, A., Rizi, V., Rocadenbosch, F., Rodríguez, A., Sauvage, L., Schmidt, J., Schnell, F., Schwarz, A., Seifert, P., Serikov, I., Sicard, M., Silva, A. M., Simeonov, V., Siomos, N., Sirch, T., Spinelli, N., Stoyanov, D., Talianu, C., Tesche, M., De Tomasi, F., Trickl, T., Vaughan, G., Volten, H., Wagner, F., Wandinger, U., Wang, X., Wiegner, M., and Wilson, K. M.: EARLINET all observa- tions (2000-2010), World Data Center for Climate (WDCC), doi:10.1594/WDCC/EN_all_measurements_2000-2010, 2014a. The EARLINET publishing group 2000-2010: Adam, M., AladosArboledas, L., Al-thausen, D., Amiridis, V., Amodeo, A., Ansmann, A., Apituley, A., Arshinov, Y., Balis, D., Belegante, L., Bobrovnikov, S., Boselli, A., Bravo-Aranda, J. A., Bösen-berg, J., Carstea, E., Chaikovsky, A., Comerón, A., D'Amico, G., Daou, D., Dreischuh, T., Engelmann, R., Finger, F., Freudenthaler, V., Garcia-Vizcaino, D., García, A. J. F., Geiß, A., Giannakaki, E., Giehl, H., Giunta, A., de Graaf, M., Granados-Muñoz, M. J., Grein, M., Grigorov, I., Groß, S., Gruening, C., Guerrero-Rascado, J. L., Haeffelin, M., Hayek, T., Iarlori, M., Kanitz, T., Kokkalis, P., Linné, H., Ma-donna, F., Mamouriat, R.E., Matthias, V., Mattis, I., Menéndez, F. M., Mitev, V., Mona, L., Morille, Y., Muñoz, C., Müller, A., Müller, D., Navas-Guzmán, F., Nemuc, A., Nicolae, D., Pandolfi, M., Papayannis, A., Pappalardo, G., Pelon, J., Perrone, M.R., Pietruczuk, A., Pisani, G., Potma, C., Preißler, J., Pujadas, M., Putaud, J., Radu, C., Ravetta, F., Reigert, A., Rizi, V., Rocadenbosch, F., Rodríguez, A., Sauvage, L., Schmidt, J., Schnell, F., Schwarz, A., Seifert, P., Serikov, I., Sicard, M., Silva, A. M., Simeonov, V., Siomos, N., Sirch, T., Spinelli, N., Stoyanov, D., Talianu, C., Tesche, M., De Tomasi, F., Trickl, T., Vaughan, G., Volten, H., Wagner, F., Wandinger, U., Wang, X., Wiegner, M., and Wilson, K. M.: EARLINET climatology (2000-2010), World Data Center for Climate (WDCC), doi:10.1594/WDCC/EN_Climatology_2000-2010,2014b.

The EARLINET publishing group 2000-2010: Adam, M., AladosArboledas, L., Al-thausen, D., Amiridis, V., Amodeo, A., Ansmann, A., Apituley, A., Arshinov, Y., Balis, D., Belegante, L., Bobrovnikov, S., Boselli, A., Bravo-Aranda, J. A., Bösen-berg, J., Carstea, E., Chaikovsky, A., Comerón, A., D’Amico, G., Daou, D., Dreischuh, T., Engelmann, R., Finger, F., Freudenthaler, V., Garcia-Vizcaino, D., García, A. J. F., Geiß, A., Giannakaki, E., Giehl, H., Giunta, A., de Graaf, M., Grana-dosMuñoz, M. J., Grein, M., Grigorov, I., Groß, S., Gruening, C., Guerrero-Rascado, J. L., Haeffelin, M., Hayek, T., Iarlori, M., Kanitz, T., Kokkalis, P., Linné, H., Ma-donna, F., Mamouriat, R.-E., Matthias, V., Mattis, I., Menéndez, F. M., Mitev, V., Mona, L., Morille, Y., Muñoz, C., Müller, A., Müller, D., NavasGuzmán, F., Nemuc, A., Nicolae, D., Pandolfi, M., Papayannis, A., Pappalardo, G., Pelon, J., Perrone, M. R., Pietruczuk, A., Pisani, G., Potma, C., Preißler, J., Pujadas, M., Putaud, J., Radu, C., Ravetta, F., Reigert, A., Rizi, V., Rocadenbosch, F., Rodríguez, A., Sauvage, L., Schmidt, J., Schnell, F., Schwarz, A., Seifert, P., Serikov, I., Sicard, M., Silva, A. M., Simeonov, V., Siomos, N., Sirch, T., Spinelli, N., Stoyanov, D., Talianu, C., Tesche, M., De Tomasi, F., Trickl, T., Vaughan, G., Volten, H., Wagner, F., Wandinger, U., Wang, X., Wiegner, M., and Wilson, K. M.: EARLINET correlative observations for CALIPSO (2006-2010),World Data Center for Climate (WDCC), doi:10.1594/WDCC/EN_Calipso_2006-2010, 2014c.

The EARLINET publishing group 2000-2010, Adam, M., AladosArboledas, L., Al-thausen, D., Amiridis, V., Amodeo, A., Ansmann, A., Apituley, A., Arshinov, Y., Balis, D., Belegante, L., Bobrovnikov, S., Boselli, A., Bravo-Aranda, J. A., Bösen-berg, J., Carstea, E., Chaikovsky, A., Comerón, A., D’Amico, G., Daou, D., Dreischuh, T., Engelmann, R., Finger, F., Freudenthaler, V., Garcia-Vizcaino, D., García, A. J. F., Geiß, A., Gi- 
annakaki, E., Giehl, H., Giunta, A., de Graaf, M., Grana-dosMuñoz, M. J., Grein, M., Grigorov, I., Groß, S., Gruening, C., Guerrero-Rascado, J. L., Haeffelin, M., Hayek, T., Iarlori, M., Kanitz, T., Kokkalis, P., Linné, H., Ma-donna, F., Mamouriat, R.-E., Matthias, V., Mattis, I., Menéndez, F. M., Mitev, V., Mona, L., Morille, Y., Muñoz, C., Müller, A., Müller, D., NavasGuzmán, F., Nemuc, A., Nicolae, D., Pandolfi, M., Papayannis, A., Pappalardo, G., Pelon, J., Perrone, M. R., Pietruczuk, A., Pisani, G., Potma, C., Preißler, J., Pujadas, M., Putaud, J., Radu, C., Ravetta, F., Reigert, A., Rizi, V., Rocadenbosch, F., Rodríguez, A., Sauvage, L., Schmidt, J., Schnell, F., Schwarz, A., Seifert, P., Serikov, I., Sicard, M., Silva, A. M., Simeonov, V., Siomos, N., Sirch, T., Spinelli, N., Stoyanov, D., Talianu, C., Tesche, M., De Tomasi, F., Trickl, T., Vaughan, G., Volten, H., Wagner, F., Wandinger, U., Wang, X., Wiegner, M., and Wilson, K. M.: EARLINET observations related to volcanic eruptions (2000-2010), World Data Center for Climate (WDCC), doi:10.1594/WDCC/EN_VolcanicEruption_2000-2010, 2014d.

The EARLINET publishing group 2000-2010: Adam, M., AladosArboledas, L., Al-thausen, D., Amiridis, V., Amodeo, A., Ansmann, A., Apituley, A., Arshinov, Y., Balis, D., Belegante, L., Bobrovnikov, S., Boselli, A., Bravo-Aranda, J. A., Bösenberg, J., Carstea, E., Chaikovsky, A., Comerón, A., D’Amico, G., Daou, D., Dreischuh, T., Engelmann, R., Finger, F., Freudenthaler, V., Garcia-Vizcaino, D., García, A. J. F., Geiß, A., Giannakaki, E., Giehl, H., Giunta, A., de Graaf, M., Grana-dosMuñoz, M. J., Grein, M., Grigorov, I., Groß, S., Gruening, C., Guerrero-Rascado, J. L., Haeffelin, M., Hayek, T., Iarlori, M., Kanitz, T., Kokkalis, P., Linné, H., Ma-donna, F., Mamouriat, R.-E., Matthias, V., Mattis, I., Menéndez, F. M., Mitev, V., Mona, L., Morille, Y., Muñoz, C., Müller, A., Müller, D., NavasGuzmán, F., Nemuc, A., Nicolae, D., Pandolfi, M., Papayannis, A., Pappalardo, G., Pelon, J., Perrone, M. R., Pietruczuk, A., Pisani, G., Potma, C., Preißler, J., Pujadas, M., Putaud, J., Radu, C., Ravetta, F., Reigert, A., Rizi, V., Rocadenbosch, F., Rodríguez, A., Sauvage, L., Schmidt, J., Schnell, F., Schwarz, A., Seifert, P., Serikov, I., Sicard, M., Silva, A. M., Simeonov, V., Siomos, N., Sirch, T., Spinelli, N., Stoyanov, D., Talianu, C., Tesche, M., De Tomasi, F., Trickl, T., Vaughan, G., Volten, H., Wagner, F., Wandinger, U., Wang, X., Wiegner, M., and Wilson, K. M.: EARLINET observations related to Saharan Dust events (2000-2010), World Data Center for Climate (WDCC), doi:10.1594/WDCC/EARLINET_SaharanDust_2000-2010, 2014e.

Eskes, H., Huijnen, V., Arola, A., Benedictow, A., Blechschmidt, A.-M., Botek, E., Boucher, O., Bouarar, I., Chabrillat, S., Cuevas, E., Engelen, R., Flentje, H., Gaudel, A., Griesfeller, J., Jones, L., Kapsomenakis, J., Katragkou, E., Kinne, S., Langerock, B., Razinger, M., Richter, A., Schultz, M., Schulz, M., Sudarchikova, N., Thouret, V., Vrekoussis, M., Wagner, A., and Zerefos, C.: Validation of reactive gases and aerosols in the MACC global analysis and forecast system, Geosci. Model Dev., 8, 3523-3543, doi:10.5194/gmd-8-3523-2015, 2015.

Evan, A. T., Flamant, C., Gaetani, M., and Guichard, F.: The past, present and future of African dust, Nature, 531, 493-495, doi:10.1038/nature17149, 2016.

Flemming, J., Huijnen, V., Arteta, J., Bechtold, P., Beljaars, A., Blechschmidt, A.-M., Diamantakis, M., Engelen, R. J., Gaudel, A., Inness, A., Jones, L., Josse, B., Katragkou, E., Marecal,
V., Peuch, V.-H., Richter, A., Schultz, M. G., Stein, O., and Tsikerdekis, A.: Tropospheric chemistry in the Integrated Forecasting System of ECMWF, Geosci. Model Dev., 8, 975-1003, doi:10.5194/gmd-8-975-2015, 2015.

Floutsi, A. A., Korras-carraca, M. B., Matsoukas, C., Hatzianastassiou, N., and Biskos, G.: Climatology and trends of aerosol optical depth over the Mediterranean basin during the last 12 years (2002-2014) based on Collection 006 MODISAqua data, Sci. Total Environ., 33, 551e552, doi:10.1016/j.scitotenv.2016.01.192, 2016.

Freudenthaler, V., Esselborn, M., Wiegner, M., Heese, B., Tesche, M., Ansmann, A., Müller, D., Althausen, D., Wirth, M., Fix, A., Ehret, G., Knippertz, P., Toledano, C., Gasteiger, J., Garhammer, M., and Seefeldner, M.: Depolarization ratio profiling at several wavelengths in pure Saharan dust during SAMUM 2006, Tellus Ser. B, 61, 165-179, doi:10.1111/j.1600-0889.2008.00396.x, 2009.

Fujita, K.: Effect of dust event timing on glacier runoff sensitivity analysis for a Tibetan glacier, Hydrol. Process., 21, 2892-2896, 2007.

Ganor, E.: The frequency of Saharan dust episodes over Tel Aviv, Israel, Atmos. Environ., 28, 2867-2871, doi:10.1016/13522310(94)90087-6, 1994.

Georgoulias, A. K., Alexandri, G., Kourtidis, K. A., Lelieveld, J., Zanis, P., Pöschl, U., Levy, R., Amiridis, V., Marinou, E., and Tsikerdekis, A.: Spatiotemporal variability and contribution of different aerosol types to the aerosol optical depth over the Eastern Mediterranean, Atmos. Chem. Phys., 16, 13853-13884, doi:10.5194/acp-16-13853-2016, 2016 .

Georgoulias, A. K., Alexandri, G., Kourtidis, K. A., Lelieveld, J., Zanis, P., and Amiridis, V.: Differences between the MODIS Collection 6 and 5.1 aerosol datasets over the greater Mediterranean region, Atmos. Environ., 147, 310-319, doi:10.1016/j.atmosenv.2016.10.014, 2016b.

Georgoulias, A. K., Tsikerdekis, A., Amiridis, V., Marinou, E., Benedetti, A., Zanis, P., and Kourtidis, K.: A 3-D Evaluation of the MACC Reanalysis Dust Product Over Europe Using CALIOP/CALIPSO Satellite Observations, in: Perspectives on Atmospheric Sciences, Proceedings of the 13th International Conference on Meteorology, Climatology and Atmospheric Physics, Thessaloniki, Greece, 19-21 September 2016, edited by: Karacostas, T., Bais, A., and Nastos, P. T., Springer Atmospheric sciences, Springer International Publishing AG, Cham, Switzerland, 795-800, 2017.

Gerasopoulos, E., Amiridis, V., Kazadzis, S., Kokkalis, P., Eleftheratos, K., Andreae, M. O., Andreae, T. W., El-Askary, H., and Zerefos, C. S.: Three-year ground based measurements of aerosol optical depth over the Eastern Mediterranean: the urban environment of Athens, Atmos. Chem. Phys., 11, 2145-2159, doi:10.5194/acp-11-2145-2011, 2011.

Giorgi, F., Coppola, E., Solmon, F., Mariotti, L., Sylla, M., Bi, X., Elguindi, N., Diro, G., Nair, V., Giuliani, G., Turuncoglu, U., Cozzini, S., Güttler, I., O’Brien, T., Tawfik, A., Shalaby, a, Zakey, A., Steiner, A., Stordal, F., Sloan, L., and Brankovic, C.: RegCM4: model description and preliminary tests over multiple CORDEX domains, Clim. Res., 52, 7-29, doi:10.3354/cr01018, 2012.

Gkikas, A., Hatzianastassiou, N., Mihalopoulos, N., Katsoulis, V., Kazadzis, S., Pey, J., Querol, X., and Torres, O.: The regime 
of intense desert dust episodes in the Mediterranean based on contemporary satellite observations and ground measurements, Atmos. Chem. Phys., 13, 12135-12154, doi:10.5194/acp-1312135-2013, 2013.

Gkikas, A., Basart, S., Hatzianastassiou, N., Marinou, E., Amiridis, V., Kazadzis, S., Pey, J., Querol, X., Jorba, O., Gassó, S., and Baldasano, J. M.: Mediterranean intense desert dust outbreaks and their vertical structure based on remote sensing data, Atmos. Chem. Phys., 16, 8609-8642, doi:10.5194/acp-16-86092016, 2016.

Gobbi, G., Barnaba, F., and Ammannato, L.: Estimating the impact of saharan dust on the year $2001 \mathrm{PM}_{10}$ record of Rome, Italy, Atmos. Environ., 41, 261-275, doi:10.1016/j.atmosenv.2006.08.036., 2007.

Granados-Muñoz, M. J., Navas-Guzmán, F., Guerrero-Rascado, J. L., Bravo-Aranda, J. A., Binietoglou, I., Pereira, S. N., Basart, S., Baldasano, J. M., Belegante, L., Chaikovsky, A., Comerón, A., D’Amico, G., Dubovik, O., Ilic, L., Kokkalis, P., Muñoz-Porcar, C., Nickovic, S., Nicolae, D., Olmo, F. J., Papayannis, A., Pappalardo, G., Rodríguez, A., Schepanski, K., Sicard, M., Vukovic, A., Wandinger, U., Dulac, F., and AladosArboledas, L.: Profiling of aerosol microphysical properties at several EARLINET/AERONET sites during the July 2012 ChArMEx/EMEP campaign, Atmos. Chem. Phys., 16, 70437066, doi:10.5194/acp-16-7043-2016, 2016.

Grell, G. A., Dudhia, J., and Stauffer, D. R.: A Description of the Fifth-Generation Penn State/NCAR Mesoscale Model (MM5), National Center for Atmospheric Research, Boulder, Colorado, 1994.

Groß, S., Tesche, M., Freudenthaler, V., Toledano, C., Wiegner, M., Ansmann, A., Althausen, D., and Seefeldner, M.: Characterization of Saharan dust, marine aerosols and mixtures of biomass burning aerosols and dust by means of multi-wavelength depolarization-and Raman-measurements during SAMUM-2, Tellus B, 63, 706-724, 2011.

Groß, S., Esselborn, M., Weinzierl, B., Wirth, M., Fix, A., and Petzold, A.: Aerosol classification by airborne high spectral resolution lidar observations, Atmos. Chem. Phys., 13, 2487-2505, doi:10.5194/acp-13-2487-2013, 2013.

Groß, S., Freudenthaler, V., Schepanski, K., Toledano, C., Schäfler, A., Ansmann, A., and Weinzierl, B.: Optical properties of longrange transported Saharan dust over Barbados as measured by dual-wavelength depolarization Raman lidar measurements, Atmos. Chem. Phys., 15, 11067-11080, doi:10.5194/acp-1511067-2015, 2015.

Guirado, C., Cuevas, E., Cachorro, V. E., Toledano, C., AlonsoPérez, S., Bustos, J. J., Basart, S., Romero, P. M., Camino, C., Mimouni, M., Zeudmi, L., Goloub, P., Baldasano, J. M., and de Frutos, A. M.: Aerosol characterization at the Saharan AERONET site Tamanrasset, Atmos. Chem. Phys., 14, 1175311773, doi:10.5194/acp-14-11753-2014, 2014.

Hsu, N. C., Tsay, S. C., King, M. D., and Herman, J. R.: Aerosol properties over bright-reflecting source regions, IEEE T. Geosci. Remote Sens., 42, 557-569, doi:10.1109/TGRS.2004.824067, 2004.

Hsu, N. C., Gautam, R., Sayer, A. M., Bettenhausen, C., Li, C., Jeong, M. J., Tsay, S.-C., and Holben, B. N.: Global and regional trends of aerosol optical depth over land and ocean using SeaW-
iFS measurements from 1997 to 2010, Atmos. Chem. Phys., 12, 8037-8053, doi:10.5194/acp-12-8037-2012, 2012.

Huang, J., Guo, J., Wang, F., Liu, Z., Jeong, M.-J., Yu, H., and Zhang, Z.: CALIPSO inferred most probable heights of global dust and smoke layers, J. Geophys. Res., 120, 5085-5100, doi:10.1002/2014JD022898, 2015a.

Huang, J. P., Liu, J. J., Chen, B., and Nasiri, S. L.: Detection of anthropogenic dust using CALIPSO lidar measurements, Atmos. Chem. Phys., 15, 11653-11665, doi:10.5194/acp-1511653-2015, 2015b.

Huneeus, N., Schulz, M., Balkanski, Y., Griesfeller, J., Prospero, J., Kinne, S., Bauer, S., Boucher, O., Chin, M., Dentener, F., Diehl, T., Easter, R., Fillmore, D., Ghan, S., Ginoux, P., Grini, A., Horowitz, L., Koch, D., Krol, M. C., Landing, W., Liu, X., Mahowald, N., Miller, R., Morcrette, J.-J., Myhre, G., Penner, J., Perlwitz, J., Stier, P., Takemura, T., and Zender, C. S.: Global dust model intercomparison in AeroCom phase I, Atmos. Chem. Phys., 11, 7781-7816, doi:10.5194/acp-11-7781-2011, 2011.

Huneeus, N., Basart, S., Fiedler, S., Morcrette, J.-J., Benedetti, A., Mulcahy, J., Terradellas, E., Pérez García-Pando, C., Pejanovic, G., Nickovic, S., Arsenovic, P., Schulz, M., Cuevas, E., Baldasano, J. M., Pey, J., Remy, S., and Cvetkovic, B.: Forecasting the northern African dust outbreak towards Europe in April 2011: a model intercomparison, Atmos. Chem. Phys., 16, 4967-4986, doi:10.5194/acp-16-4967-2016, 2016.

ICARE Data Center: CALIPSO data, available at: http://www.icare. univ-lille1.fr/, last access: 5 December 2016.

Illingworth, A. J., Barker, H. W., Beljaars, A., Ceccaldi, M., Chepfer, H., Clerbaux, N., Cole, J., Delanoë, J., Domenech, C., Donovan, D. P., Fukuda, S., Hirakata, M., Hogan, R.J., Huenerbein, A., Kollias, P., Nakajima, T., Nakajima, T.-Y., Nishizawa, T., Ohno, Y., Okamoto, H., Oki, R., Sato, K., Satoh, M., Sephard, M. W., Velázquez-Blázquez, A., Wandinger, U., Wehr, T., and van Zadelhoff, G.-J.: The EarthCARE Satellite: The Next Step Forward in Global Measurements of Clouds, Aerosols, Precipitation, and Radiation, B. Am. Meteorol. Soc., 96, 1311-1332, doi:10.1175/BAMS-D-12-00227.1, 2015.

Ingmann, P., Veihelmann, B., Langen, J., Lamarre, D., Stark, H., and Bazalgette Courrèges-Lacoste, G.: Requirements for the GMES Atmosphere Service and ESA's implementation concept: Sentinels-4/5 and -5p, Remote Sens. Environ., 120, 58-69, doi:10.1016/j.rse.2012.01.023, 2012.

Inness, A., Baier, F., Benedetti, A., Bouarar, I., Chabrillat, S., Clark, H., Clerbaux, C., Coheur, P., Engelen, R. J., Errera, Q., Flemming, J., George, M., Granier, C., Hadji-Lazaro, J., Huijnen, V., Hurtmans, D., Jones, L., Kaiser, J. W., Kapsomenakis, J., Lefever, K., Leitão, J., Razinger, M., Richter, A., Schultz, M. G., Simmons, A. J., Suttie, M., Stein, O., Thépaut, J.-N., Thouret, V., Vrekoussis, M., Zerefos, C., and the MACC team: The MACC reanalysis: an 8 yr data set of atmospheric composition, Atmos. Chem. Phys., 13, 4073-4109, doi:10.5194/acp-13-4073-2013, 2013.

IPCC 2013: Climate Change 2013: The Physical Science Basis. Contribution of Working Group I to the Fifth Assessment Report of the Intergovernmental Panel on Climate Change, edited by: Stocker, T. F., Qin, D., Plattner, G.K., Tignor, M., Allen, S. K., Boschung, J., Nauels, A., Xia, Y., Bex, V., and Midgley, P. M., Cambridge University Press, Cambridge, UK and New York, NY, USA, 1535 
pp., available at: https://www.ipcc.ch/pdf/assessment-report/ar5/ wg1/WG1AR5_Frontmatter_FINAL.pdf (last access: 30 August 2016), 2013.

Israelevich, P., Ganor, E., Alpert, P., Kishcha, P., and Stupp, A.: Predominant transport paths of Saharan dust over the Mediterranean Sea to Europe, J. Geophys. Res., 117, D02205, doi:10.1029/2011JD016482, 2012.

Israelevich, P. L., Levin, Z., Joseph, J. H., and Ganor, E.: Desert aerosol transport in the Mediterranean region as inferred from the TOMS aerosol index, J. Geophys. Res., 107, 4572, doi:10.1029/2001JD002011, 2002.

Kanitz, T., Ansmann, A., Engelmann, R., and Althausen, D.: Northsouth cross sections of the vertical aerosol distribution over the Atlantic Ocean from multiwavelength Raman/polarization lidar during Polarstern cruises, J. Geophys. Res., 118, 2643-2655, doi:10.1002/jgrd.50273, 2013.

Katragkou, E., Zanis, P., Tsikerdekis, A., Kapsomenakis, J., Melas, D., Eskes, H., Flemming, J., Huijnen, V., Inness, A., Schultz, M. G., Stein, O., and Zerefos, C. S.: Evaluation of near-surface ozone over Europe from the MACC reanalysis, Geosci. Model Dev., 8, 2299-2314, doi:10.5194/gmd-8-2299-2015, 2015.

Kaufman, Y. J., Remer, L. A., Tanré, D., Li, R.-R., Kleidman, R., Matoo, S., Levy, R., Eck, T., Holben, B. N., Ichoku, C., Martins, V., and Koren, I.: A Critical Examination of the Residual Cloud Contamination and Diurnal Sampling Effects on MODIS Estimates of Aerosol over Ocean, IEEE T. Geosci. Remote Sens., 43, 2886-2897, doi:10.1109/TGRS.2005.858430, 2005.

Kim, M.-H., Omar, A. H., Vaughan, M. A., Winker, D. M., Trepte, C. R., Hu, Y., Liu, Z., and Kim, S.-W.: Quantifying the low bias of CALIPSO's column aerosol optical depth due to undetected aerosol layers, J. Geophys. Res.-Atmos., 122, 1098-1113, doi:10.1002/2016JD025797, 2017.

Kinnison, D. E., Brasseur, G. P., Walters, S., Garcia, R. R., Marsh, D. R., Sassi, F., Harvey, V. L., Randall, C. E., Emmons, L., Lamarque, J. F., Hess, P., Orlando, J. J., Tie, X. X., Randel, W., Pan, L. L., Gettelman, A., Granier, C., Diehl, T., Niemeier, U., and Simmons, A. J.: Sensitivity of chemical tracers to meteorological parameters in the MOZART-3 chemical transport model, J. Geophys. Res. Atmos., 112, 1-24, doi:10.1029/2006JD007879, 2007.

Knippertz, P., Trentmann, J., and Seifert, A.: High resolution simulations of convective cold pools over the northwestern Sahara, J. Geophys. Res., 114, D21109, doi:10.1029/2007JD008774, 2009.

Koren, I., Feingold, G., and Remer, L. A.: The invigoration of deep convective clouds over the Atlantic: aerosol effect, meteorology or retrieval artifact?, Atmos. Chem. Phys., 10, 8855-8872, doi:10.5194/acp-10-8855-2010, 2010.

Kosmopoulos, P. G., Kaskaoutis, D. G., Nastos, P. T., and Kambezidis, H. D.: Seasonal variation of columnar aerosol optical properties over Athens, Greece, based on MODIS data, Remote Sens. Environ., 112, 2354-2366, doi:10.1016/j.rse.2007.11.006, 2008.

Lelieveld, J., Berresheim, H., Borrmann, S., Crutzen, P. J., Dentener, F. J., Fischer, H., Feichter, J., Flatau, P. J., Heland, J., Holzinger, R., Korrmann, R., Lawrence, M. G., Levin, Z., Markowicz, K. M., Mihalopoulos, N., Minikin, A., Ramanathan, V., de Reus, M., Roelofs, G. J., Scheeren, H. A., Sciare, J., Schlanger, H., Schultz, M., Siegmund, P., Steil, B., Stephanou, E. G., Stier, P., Traub, M., Warneke, C., Williams, J., and Ziereis,
H.: Global Air Pollution Crossroads over the Mediterranean, Science, 298, 794-799, doi:10.1126/science.1075457, 2002.

Levin, Z., Teller, A., Ganor, E., and Yin, Y.: On the interactions of mineral dust, sea-salt particles, and clouds: A measurement and modeling study from the Mediterranean Israeli Dust Experiment campaign, J. Geophys. Res., 110, D20202, doi:10.1029/2005JD005810, 2005.

Lopes, F. J. S., Landulfo, E., and Vaughan, M. A.: Evaluating CALIPSO's $532 \mathrm{~nm}$ lidar ratio selection algorithm using AERONET sun photometers in Brazil, Atmos. Meas. Tech., 6, 3281-3299, doi:10.5194/amt-6-3281-2013, 2013.

Liu, Z., Sugimoto, N., and Murayama, T.: Extinction-tobackscatter ratio of Asian dust observed with high-spectralresolution lidar and Raman lidar, Appl. Optics, 41, 2760, doi:10.1364/AO.41.002760, 2002.

Liu, D., Wang, Z., Liu, Z., Winker, D., and Trepte, C.: A height resolved global view of dust aerosols from the first year CALIPSO lidar measurements, J. Geophys. Res., 113, D16214, doi:10.1029/2007JD009776, 2008.

Liu, Z., Omar, A., Vaughan, M., Hair, J., Kittaka, C., Hu, Y., Powell, K., Trepte, C., Winker, D., Hostetler, C., Ferrare, R., and Pierce, R.: CALIPSO lidar observations of the optical properties of Saharan dust: A case study of long-range transport, J. Geophys. Res., 113, D07207, doi:10.1029/2007JD008878, 2008.

Maheras, P., Flocas, H. A., Patrikas, I., and Anagnostopoulou, C.: A 40 year objective climatology of surface cyclones in the Mediterranean region: spatial and temporal distribution, Int. J. Climatol., 21, 109-130, doi:10.1002/joc.599, 2001.

Mamouri, R. E. and Ansmann, A.: Fine and coarse dust separation with polarization lidar, Atmos. Meas. Tech., 7, 3717-3735, doi:10.5194/amt-7-3717-2014, 2014.

Mamouri, R. E. and Ansmann, A.: Estimated desert-dust ice nuclei profiles from polarization lidar: methodology and case studies, Atmos. Chem. Phys., 15, 3463-3477, doi:10.5194/acp-15-34632015, 2015.

Mamouri, R.-E. and Ansmann, A.: Potential of polarization lidar to provide profiles of $\mathrm{CCN}$ - and INP-relevant aerosol parameters, Atmos. Chem. Phys., 16, 5905-5931, doi:10.5194/acp-16-59052016, 2016.

Mamouri, R. E., Amiridis, V., Papayannis, A., Giannakaki, E., Tsaknakis, G., and Balis, D. S.: Validation of CALIPSO spaceborne-derived attenuated backscatter coefficient profiles using a ground-based lidar in Athens, Greece, Atmos. Meas. Tech., 2, 513-522, doi:10.5194/amt-2-513-2009, 2009.

Marey, H. S., Gille, J. C., El-Askary, H. M., Shalaby, E. A., and El-Raey, M. E.: Aerosol climatology over Nile Delta based on MODIS, MISR and OMI satellite data, Atmos. Chem. Phys., 11, 10637-10648, doi:10.5194/acp-11-10637-2011, 2011.

Mariotti, A., Struglia, M.V., Zeng, N., and Lau, K.-M.: The Hydrological Cycle in the Mediterranean Region and Implications for the Water Budget of the Mediterranean Sea, J. Climate, 15, 1674-1690, doi:10.1175/15200442(2002)015<1674:THCITM>2.0.CO;2, 2002.

Mona, L., Amodeo, A., Pandolfi, M., and Pappalardo, G.: Saharan dust intrusions in the Mediterranean area: three years of Raman lidar measurements, J. Geophys. Res.-Atmos., 111, d16203, doi:10.1029/2005JD006569, 2006.

Mona, L., Liu, Z., Müller, D., Omar, A., Papayannis, A., Sugimoto, N., Pappalardo, G., and Vaughan, M.: Lidar Measurements 
for Desert Dust Characterization: An Overview, Adv. Meteorol., 2012, 36 pp., doi:10.1155/2012/356265, 2012.

Mona, L., Papagiannopoulos, N., Basart, S., Baldasano, J., Binietoglou, I., Cornacchia, C., and Pappalardo, G.: EARLINET dust observations vs. BSC-DREAM8b modeled profiles: 12year-long systematic comparison at Potenza, Italy, Atmos. Chem. Phys., 14, 8781-8793, doi:10.5194/acp-14-8781-2014, 2014.

Moulin, C, Lambert, C. E., Dayan, U., Masson, V., Ramonet, M., Bousquet, P., Legrand, M., Balkanski, Y. J., Guelle, W., Marticorena, B., Bergametti, F., and Dulac, F.: Satellite climatology of African dust transport in the Mediterranean atmosphere, J. Geophys. Res., 103, 13137-13144, doi:10.1029/98JD00171, 1998.

Müller, D., Mattis, I., Wandinger, U., Ansmann, A., Althausen, D., Dubovik, O., Eckhardt, S., and Stohl, A.: Saharan dust over a central European EARLINET-AERONET site: Combined observations with Raman lidar and Sun photometer, J. Geophys. Res., 108, 4345, doi:10.1029/2002JD002918, 2003.

Nabat, P., Solmon, F., Mallet, M., Kok, J. F., and Somot, S.: Dust emission size distribution impact on aerosol budget and radiative forcing over the Mediterranean region: a regional climate model approach, Atmos. Chem. Phys., 12, 10545-10567, doi:10.5194/acp-12-10545-2012, 2012.

Nabat, P., Somot, S., Mallet, M., Chiapello, I., Morcrette, J. J., Solmon, F., Szopa, S., Dulac, F., Collins, W., Ghan, S., Horowitz, L. W., Lamarque, J. F., Lee, Y. H., Naik, V., Nagashima, T., Shindell, D., and Skeie, R.: A 4-D climatology (1979-2009) of the monthly tropospheric aerosol optical depth distribution over the Mediterranean region from a comparative evaluation and blending of remote sensing and model products, Atmos. Meas. Tech., 6, 1287-1314, doi:10.5194/amt-6-1287-2013, 2013.

Nickovic, S., Cvetkovic, B., Madonna, F., Rosoldi, M., Pejanovic, G., Petkovic, S., and Nikolic, J.: Cloud ice caused by atmospheric mineral dust - Part 1: Parameterization of ice nuclei concentration in the NMME-DREAM model, Atmos. Chem. Phys., 16, 11367-11378, doi:10.5194/acp-16-11367-2016, 2016.

Omar, A., Winker, D., Kittaka, C., Vaughan, M., Liu, Z., Hu, Y. X., Trepte, C., Rogers, R., Ferrare, R., Lee, K., Kuehn, R., and Hostetler, C.: The CALIPSO automated aerosol classification and lidar ratio selection algorithm, J. Atmos. Ocean. Tech., 26, 1994-2014, doi:10.1175/2009jtecha1231.1, 2009.

Papadimas, C. D., Hatzianastassiou, N., Mihalopoulos, N., Querol, X., and Vardavas, I.: Spatial and temporal variability in aerosol properties over the Mediterranean basin based on 6year (2000-2006) MODIS data, J. Geophys. Res., 113, D11205, doi:10.1029/2007JD009189, 2008.

Papagiannopoulos, N., Mona, L., Alados-Arboledas, L., Amiridis, V., Baars, H., Binietoglou, I., Bortoli, D., D’Amico, G., Giunta, A., Guerrero-Rascado, J. L., Schwarz, A., Pereira, S., Spinelli, N., Wandinger, U., Wang, X., and Pappalardo, G.: CALIPSO climatological products: evaluation and suggestions from EARLINET, Atmos. Chem. Phys., 16, 2341-2357, doi:10.5194/acp16-2341-2016, 2016.

Papayannis, A., Balis, D., Amiridis, V., Chourdakis, G., Tsaknakis, G., Zerefos, C., Castanho, A. D. A., Nickovic, S., Kazadzis, S., and Grabowski, J.: Measurements of Saharan dust aerosols over the Eastern Mediterranean using elastic backscatter-Raman lidar, spectrophotometric and satellite observations in the frame of the EARLINET project, Atmos. Chem. Phys., 5, 2065-2079, doi:10.5194/acp-5-2065-2005, 2005.
Papayannis, A., Amiridis, V., Mona, L., Tsaknakis, G., Balis, D., Bösenberg, J., Chaikovski, A., De Tomasi, F., Grigorov, I., Mattis, I., Mitev, V., Müller, D., Nickovic, S., Pérez, C., Pietruczuk, A., Pisani, G., Ravetta, F., Rizi, V., Sicard, M., Trickl, T., Wiegner, M., Gerding, M., Mamouri, R. E., D’Amico, G., and Pappalardo, G.: Systematic lidar observations of Saharan dust over Europe in the frame of EARLINET (2000-2002), J. Geophys. Res., 113, D10204, doi:10.1029/2007JD009028, 2008.

Pappalardo, G., Wandinger, U., Mona, L., Hiebsch, A., Mattis, I., Amodeo, A., Ansmann, A., Seifert, P., Linné, H., Apituley, A., Alados Arboledas, L., Balis, D., Chaikovsky, A., D’Amico, G., De Tomasi, F., Freudenthaler, V., Giannakaki, E., Giunta, A., Grigorov, I., Iarlori, M., Madonna, F., Mamouri, R., Nasti, L., Papayannis, A., Pietruczuk, A., Pujadas, M., Rizi, V., Rocadenbosch, F., Russo, F., Schnell, F., Spinelli, N., Wang, X., and Wiegner, M.: EARLINET correlative measurements for CALIPSO: first intercomparison results, J. Geophys. Res., 115, D00H19, doi:10.1029/2009JD012147, 2010.

Pappalardo, G., Amodeo, A., Apituley, A., Comeron, A., Freudenthaler, V., Linné, H., Ansmann, A., Bösenberg, J., D’Amico, G., Mattis, I., Mona, L., Wandinger, U., Amiridis, V., AladosArboledas, L., Nicolae, D., and Wiegner, M.: EARLINET: towards an advanced sustainable European aerosol lidar network, Atmos. Meas. Tech., 7, 2389-2409, doi:10.5194/amt-7-23892014, 2014.

Pey, J., Querol, X., Alastuey, A., Forastiere, F., and Stafoggia, M.: African dust outbreaks over the Mediterranean Basin during 2001-2011: $\mathrm{PM}_{10}$ concentrations, phenomenology and trends, and its relation with synoptic and mesoscale meteorology, Atmos. Chem. Phys., 13, 1395-1410, doi:10.5194/acp-13-13952013, 2013.

Popp, T., de Leeuw, G., Bingen, C., Brühl, C., Capelle, V., Chedin, A., Clarisse, L., Dubovik, O., Grainger, R., Griesfeller, J., Heckel, A., Kinne, S., Klüser, L., Kosmale, M., Kolmonen, P., Lelli, L., Litvinov, P., Mei, L., North, P., Pinnock, S., Povey, A., Robert, C., Schulz, M., Sogacheva, L., Stebel, K., Stein Zweers, D., Thomas, G., Tilstra, L. G., Vandenbussche, S., Veefkind, P., Vountas, M., and Xue, Y.: Development, Production and Evaluation of Aerosol Climate Data Records from European Satellite Observations (Aerosol_cci), Remote Sens., 8, 421, doi:10.3390/rs8050421, 2016.

Pozzer, A., de Meij, A., Yoon, J., Tost, H., Georgoulias, A. K., and Astitha, M.: AOD trends during 2001-2010 from observations and model simulations, Atmos. Chem. Phys., 15, 5521-5535, doi:10.5194/acp-15-5521-2015, 2015.

Preißler, J., Bravo-Aranda, J. A., Wagner, F., Granados-Muñoz, M. J., Navas-Guzmán, F., Guerrero-Rascado, J. L., Lyamani, H., and Alados-Arboledas, L.: Combined observations with multiwavelength Raman lidars and sun photometers on the southern Iberian Peninsula, European Aerosol Conference 2012, Granada, Spain, 2012.

Prospero, J. M. and Lamb, P. J.: African Droughts and Dust Transport to the Caribbean: Climate Change Implications, Science, 302, 1024-1027, doi:10.1126/science.1089915, 2003.

Prospero, J. M., Ginoux, P., Torres, O., Nicholson, S. E., and Gill, T. E.: Environmental Characterization of Global Sources of Atmospheric Soil Dust Identified with the NIMBUS 7 Total Ozone Mapping Spectrometer (TOMS) Absorbing Aerosol 
Product, Rev. Geophys., 40, 1002, doi:10.1029/2000RG000095, 2002.

Ridley, D. A., Heald, C. L., and Ford, B.: North African dust export and deposition: A satellite and model perspective, J. Geophys. Res., 117, D02202, doi:10.1029/2011JD016794, 2012.

Rogers, R. R., Vaughan, M. A., Hostetler, C. A., Burton, S. P., Ferrare, R. A., Young, S. A., Hair, J. W., Obland, M. D., Harper, D. B., Cook, A. L., and Winker, D. M.: Looking through the haze: evaluating the CALIPSO level 2 aerosol optical depth using airborne high spectral resolution lidar data, Atmos. Meas. Tech., 7, 4317-4340, doi:10.5194/amt-7-4317-2014, 2014.

Sakai, T., Shibata, T., Kwon, S-A., Kim, Y.-S., Tamura, K., and Iwasaka Y.: Free tropospheric aerosol backscatter, depolarization ratio, and relative humidity measured with the Raman lidar at Nagoya in 1994-1997: contributions of aerosols from the Asian continent and the pacific ocean, Atmos. Environ., 34, 431-442, doi:10.1016/S1352-2310(99)00328-3, 2000.

Sanders, A. F. J., de Haan, J. F., Sneep, M., Apituley, A., Stammes, P., Vieitez, M. O., Tilstra, L. G., Tuinder, O. N. E., Koning, C. E., and Veefkind, J. P.: Evaluation of the operational Aerosol Layer Height retrieval algorithm for Sentinel-5 Precursor: application to $\mathrm{O}_{2}$ A band observations from GOME-2A, Atmos. Meas. Tech., 8, 4947-4977, doi:10.5194/amt-8-4947-2015, 2015.

Sayer, A. M., Hsu, N. C., Bettenhausen, C., Jeong, M.-J., Holben, B. N., and Zhang, J.: Global and regional evaluation of overland spectral aerosol optical depth retrievals from SeaWiFS, Atmos. Meas. Tech., 5, 1761-1778, doi:10.5194/amt-5-1761-2012, 2012.

Sayer, A. M., Munchak, L. A., Hsu, N. C., Levy, R. C., Bettenhausen, C., and Jeong, M.-J.: MODIS Collection 6 aerosol products: Comparison between Aqua's e-Deep Blue, Dark Target, and "merged" data sets, and usage recommendations, J. Geophys. Res.-Atmos., 119, 13965-13989, doi:10.1002/2014JD022453, 2014.

Schepanski, K., Tegen, I., Laurent, B., Heinold, B., and Macke, A.: A new Saharan dust source activation frequency map derived from MSG-SEVIRI IR-channels, Geophys. Res. Lett., 34, L18803, doi:10.1029/2007GL030168, 2007.

Schepanski, K., Tegen, I., Todd, M. C., Heinold, B., Bönisch, G., Laurent, B., and Macke, A.: Meteorological processes forcing Saharan dust emission inferred from MSG-SEVIRI observations of subdaily dust source activation and numerical models, J. Geophys. Res., 114, D10201, doi:10.1029/2008JD010325, 2009.

Schuster, G. L., Vaughan, M., MacDonnell, D., Su, W., Winker, D., Dubovik, O., Lapyonok, T., and Trepte, C.: Comparison of CALIPSO aerosol optical depth retrievals to AERONET measurements, and a climatology for the lidar ratio of dust, Atmos. Chem. Phys., 12, 7431-7452, doi:10.5194/acp-12-7431-2012, 2012.

Shahgedanova, M., Kutuzov, S., White, K. H., and Nosenko, G.: Using the significant dust deposition event on the glaciers of Mt. Elbrus, Caucasus Mountains, Russia on 5 May 2009 to develop a method for dating and "provenancing" of desert dust events recorded in snow pack, Atmos. Chem. Phys., 13, 1797-1808, doi:10.5194/acp-13-1797-2013, 2013.

Shao, Y., Klose, M., and Wyrwoll, K.-H.: Recent global dust trend and connections to climate forcing, J. Geophys. Res.-Atmos., 118, 11107-11118, doi:10.1002/jgrd.50836, 2013.
Solomos, S., Kallos, G., Mavromatidis, E., and Kushta, J.: Density currents as a desert dust mobilization mechanism, Atmos. Chem. Phys., 12, 11199-11211, doi:10.5194/acp-12-11199-2012, 2012.

Su, W., Loeb, N. G., Schuster, G. L., Chin, M., and Rose, F. G.: Global all-sky shortwave direct radiative forcing of anthropogenic aerosols from combined satellite observations and GOCART simulations, J. Geophys. Res.-Atmos., 118, 655-669, 2013.

Tesche, M., Ansmann, A., Müller, D., Althausen, D., Engelmann, R., Freudenthaler, V., and Grob, S.: Vertically Resolved Separation of Dust and Smoke over Cape Verde Using Multiwavelength Raman and Polarization Lidars during Saharan Mineral Dust Experiment 2008, J. Geophys. Res., 114, D13202, doi:10.1029/2009JD011862, 2009.

Tesche, M., Müller, D., Groß, S., Ansmann, A., Althausen, D., Freudenthaler, V., Weinzierl, B., Veira, A., and Petzold, A.: Optical and microphysical properties of smoke over Cape Verde inferred from multiwavelength lidar measurements, Tellus B, 63, 677-694, doi:10.1111/j.1600-0889.2011.00549.x, 2011.

Tesche, M., Wandinger, U., Ansmann, A., Althausen, D., Müller, D., and Omar, A. H.: Ground-based validation of CALIPSO observations of dust and smoke in the Cape Verde region, J. Geophys. Res. Atmos., 118, 2889-2902, doi:10.1002/jgrd.50248, 2013.

Textor, C., Schulz, M., Guibert, S., Kinne, S., Balkanski, Y., Bauer, S., Berntsen, T., Berglen, T., Boucher, O., Chin, M., Dentener, F., Diehl, T., Easter, R., Feichter, H., Fillmore, D., Ghan, S., Ginoux, P., Gong, S., Grini, A., Hendricks, J., Horowitz, L., Huang, P., Isaksen, I., Iversen, I., Kloster, S., Koch, D., Kirkevåg, A., Kristjansson, J. E., Krol, M., Lauer, A., Lamarque, J. F., Liu, X., Montanaro, V., Myhre, G., Penner, J., Pitari, G., Reddy, S., Seland, $\emptyset .$, Stier, P., Takemura, T., and Tie, X.: Analysis and quantification of the diversities of aerosol life cycles within AeroCom, Atmos. Chem. Phys., 6, 1777-1813, doi:10.5194/acp-6-1777-2006, 2006.

Trigo, I. F., Davies, T. D., and Bigg, G. R.: Objective climatology of cyclones in the Mediterranean region, J. Climate 12, 1685-1696, doi:10.1175/1520-0442(1999)012<1685:OCOCIT>2.0.CO;2, 1999.

Tsamalis, C., Chédin, A., Pelon, J., and Capelle, V.: The seasonal vertical distribution of the Saharan Air Layer and its modulation by the wind, Atmos. Chem. Phys., 13, 11235-11257, doi:10.5194/acp-13-11235-2013, 2013.

Tsikerdekis, A., Zanis, P., Steiner, A. L., Solmon, F., Amiridis, V., Marinou, E., Katragkou, E., Karacostas, T., and Foret, G.: Impact of dust size parameterizations on aerosol burden and radiative forcing in RegCM4, Atmos. Chem. Phys., 17, 769-791, doi:10.5194/acp-17-769-2017, 2017.

Vaughan, M. A., Powell, K. A., Kuehn, R. E., Young, S. A., Winker, D. M., Hostetler, C. A., Hunt, W. H., Liu, Z., Mcgill, M. J., and Getzewich, B. J.: Fully automated detection of cloud and aerosol layers in the CALIPSO lidar measurements, J. Atmos. Ocean. Tech., 26, 2034-2050, doi:10.1175/2009JTECHA1228.1, 2009.

Veselovskii, I., Goloub, P., Podvin, T., Bovchaliuk, V., Derimian, Y., Augustin, P., Fourmentin, M., Tanre, D., Korenskiy, M., Whiteman, D. N., Diallo, A., Ndiaye, T., Kolgotin, A., and Dubovik, O.: Retrieval of optical and physical properties of African dust from multiwavelength Raman lidar measurements during the 
SHADOW campaign in Senegal, Atmos. Chem. Phys., 16, 70137028, doi:10.5194/acp-16-7013-2016, 2016.

Viana, M., Querol, X., Alastuey, A., Cuevas, E., and Rodríguez, S.:Influence of African dust on the levels of atmospheric particulates in the Canary Islands air quality network, Atmos. Environ., 36, 5861-5875, doi:10.1016/S1352-2310(02)00463-6, 2002.

Wandinger, U., Tesche, M., Seifert, P., Ansmann, A., Müller, D., and Althausen, D.: Size matters: Influence of multiple scattering on CALIPSO light-extinction profiling in desert dust, Geophys. Res. Lett., 37, L10801, doi:10.1029/2010GL042815, 2010.

Winker, D. M., Vaughan, M. A., Omar, A. H., Hu, Y., Powell, K. A., Liu, Z., Hunt, W. H., and Young, S. A.: Overview of the CALIPSO Mission and CALIOP Data Processing Algorithms, J. Atmos. Ocean. Tech., 26, 2310-2323, doi:10.1175/2009JTECHA1281.1, 2009.

Winker, D. M., Tackett, J. L., Getzewich, B. J., Liu, Z., Vaughan, M. A., and Rogers, R. R.: The global 3-D distribution of tropospheric aerosols as characterized by CALIOP, Atmos. Chem. Phys., 13, 3345-3361, doi:10.5194/acp-13-3345-2013, 2013.

Yang, W., Marshak, A., Várnai, T., Kalashnikova, O. V., and Kostinski, A. B.: CALIPSO observations of transatlantic dust: vertical stratification and effect of clouds, Atmos. Chem. Phys., 12, 11339-11354, doi:10.5194/acp-12-11339-2012, 2012.

Yoon, J., von Hoyningen-Huene, W., Kokhanovsky, A. A., Vountas, M., and Burrows, J. P.: Trend analysis of aerosol optical thickness and Ångström exponent derived from the global AERONET spectral observations, Atmos. Meas. Tech., 5, 12711299, doi:10.5194/amt-5-1271-2012, 2012.
Yorks, J. E., McGill, M., Rodier, S., Vaughan, M., Hu, Y., and Hlavka, D.: Radiative effects of African dust and smoke observed from Clouds and the Earth's Radiant Energy System (CERES) and Cloud-Aerosol Lidar with Orthogonal Polarization (CALIOP) data, J. Geophys. Res., 114, D00H04, doi:10.1029/2009JD012000, 2009.

Young, S.: CALIOP V3 Extinction Uncertainty: Uncertainty Analysis for Particulate Backscatter, Extinction and Optical Depth Retrievals reported in the CALIPSO Level 2, Version 3 Data Release, available at: https://eosweb.larc.nasa.gov/sites/default/files/project/calipso/ CALIOP_Version3_Extinction_Error_Analysis.pdf (last access: 1 March 2017), 2010.

Young, S. and Vaughan, M.: The retrieval of profiles of particulate extinction from Cloud Aerosol Lidar Infrared Pathfinder Satellite, Observations (CALIPSO) data: algorithm description, J. Atmos. Ocean. Tech., 26, 1105-1119, doi:10.1175/2008JTECHA1221.1, 2009.

Zanis, P., Maillard, E., Stahelin, J., Zerefos, C., Kosmidis, E., and Tourpali, K.: On the turnaround of stratospheric ozone trends deduced from the re-evaluated Umkehr record of Arosa, Switzerland, J. Geophys. Res., 111, D22307, doi:10.1029/2005JD006886, 2006.

Zender, C. S., Miller, R. L., and Tegen, I.: Quantifying mineral dust mass budgets: Terminology, constraints, and current estimates, Eos Trans. Amer. Geophys. Union, 85, no. 48, 509-512, 2004. 